Article

\title{
Life Cycle Climate Change Impact of a Cost-Optimal HVDC Connection to Import Solar Energy from Australia to Singapore
}

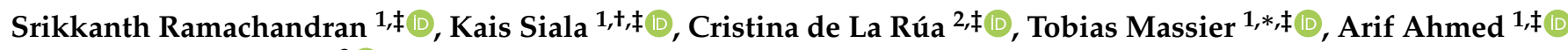 \\ and Thomas Hamacher ${ }^{2}$ (D) \\ 1 TUMCREATE Ltd., Singapore 138602, Singapore; srikkanth.rama@tum-create.edu.sg (S.R.); \\ siala@pik-potsdam.de (K.S.); arif.ahmed@tum-create.edu.sg (A.A.) \\ 2 Chair for Renewable and Sustainable Energy Systems, Technical University of Munich, \\ 80333 Munich, Germany; cristina.de-la-rua@tum.de (C.d.L.R.); thomas.hamacher@tum.de (T.H.) \\ * Correspondence: tobias.massier@tum-create.edu.sg \\ + Current address: Potsdam Institute for Climate Impact Research, 14473 Potsdam, Germany. \\ $\ddagger \quad$ These authors contributed equally to this work.
}

check for

updates

Citation: Ramachandran, S.; Siala, K.; de la Rúa, C.; Massier, T.; Ahmed, A.; Hamacher, T. Life Cycle Climate Change Impact of a Cost-Optimal HVDC Connection to Import Solar Energy from Australia to Singapore. Energies 2021, 14, 7178.

https://doi.org/10.3390/en14217178

Academic Editors: Olivier Bahn and Luigi Aldieri

Received: 27 August 2021

Accepted: 25 October 2021

Published: 1 November 2021

Publisher's Note: MDPI stays neutral with regard to jurisdictional claims in published maps and institutional affiliations.

Copyright: (C) 2021 by the authors. Licensee MDPI, Basel, Switzerland. This article is an open access article distributed under the terms and conditions of the Creative Commons Attribution (CC BY) license (https:// creativecommons.org/licenses/by/ $4.0 /)$.
Abstract: This paper aims to evaluate the life cycle greenhouse gas (GHG) emissions of importing electrical power into Singapore, generated from a large-scale solar photovoltaic (PV) power plant in Australia, through a long-distance subsea high-voltage direct current (HVDC) cable. A cost optimization model was developed to estimate the capacities of the system components. A comprehensive life cycle assessment model was built to estimate emissions of manufacturing and use of these components. Our evaluation shows that, for covering one fifth of Singapore's electrical energy needs, a system with an installed capacity of $13 \mathrm{GW}$ PV, $17 \mathrm{GWh}$ battery storage and $3.2 \mathrm{GW}$ subsea cable is required. The life cycle GHG emissions of such a system are estimated to be $110 \mathrm{gCO}_{2} \mathrm{eq} / \mathrm{kWh}$, with the majority coming from the manufacturing of solar PV panels. Cable manufacturing does not contribute largely toward GHG emissions. By varying full-load hours and cable lengths, it was assessed that sites closer to Singapore might provide the same energy at same/lower carbon footprint and reduced cost, despite the lower insolation as compared to Australia. However, these sites could cause greater emissions from land use changes than the deserts of Australia, offsetting the advantages of a shorter HVDC cable.

Keywords: life cycle assessment; cost optimization; HVDC cable; photovoltaics; Australia; Singapore

\section{Introduction \\ 1.1. Background}

The Paris Agreement under the United Nations Framework Convention on Climate Change from December 2015 has been signed by more than 190 countries so far. Singapore, a city-state located in Southeast Asia near the equator, committed to reducing its emission intensity by $36 \%$ by 2030, compared to 2005 levels. From 2030 onward, the emission intensity is to remain at this value [1].

With 95\% of Singapore's electricity being generated from natural gas [1], Singapore needs to identify low-carbon power generation alternatives to meet its long-term emission goals. At present, nuclear power has been ruled out due to safety concerns. Furthermore, with its small land area of $725 \mathrm{~km}^{2}$, Singapore's options to deploy renewable energy sources are strongly limited. The potential for wind power is low due to low wind speeds [2]. The only viable source of renewable energy within Singapore is identified to be solar photovoltaic (PV) installations on rooftops and facades of buildings or floating PV installations on water surfaces [3]. However, as space is limited, this is estimated to cover a maximum of $7.4 \%$ of its electricity demand by 2050. [4].

An alternative to reduce carbon emissions could be to import electricity or fuels produced from low carbon renewable resources from other countries. Connecting Singapore's 
grid to its neighbors in the Association of Southeast Asian Nations (ASEAN) has been discussed in various studies such as [5,6]. Many studies analyzed the potential of renewable energy in ASEAN $[7,8]$ and the challenges and benefits of interconnecting the national grids in the whole ASEAN, e.g., [9-13]. However, the vastly increasing demand in ASEAN has led to considerable increase of power generation capacities in the region-mainly from fossil energy carriers, which would not solve the problem. Hence, import of renewable energy from more distant countries is an option to consider for Singapore to reduce greenhouse gas (GHG) emissions.

In 2019, a project called "Sun Cable" was announced [14]. The idea behind this project is to generate electricity from a solar PV installation supported by a battery system in Tennant Creek in the Northern Territory of Australia and transmit power to Singapore via a $3800 \mathrm{~km}$ long subsea high-voltage direct current (HVDC) cable (the longest in the world) supplying $20 \%$ of Singapore's electricity demand. The anticipated PV capacity in Tennant Creek is $17 \mathrm{GW}_{\mathrm{p}}$ to $20 \mathrm{GW}_{\mathrm{p}}$ and the battery capacity is expected to be $36 \mathrm{GWh}$ to $42 \mathrm{GWh}$. Power is then transmitted to Darwin via an $800 \mathrm{~km}$ long transmission line. Most of the power will be transmitted to Indonesia and Singapore, while a small portion will supply Darwin's electricity demand.

In this paper, we analyze the potential environmental impacts of a long-distance connection between Australia and Singapore in terms of $\mathrm{CO}_{2}$ emissions per $\mathrm{kWh}$ provided to Singapore, taking into account the whole system. Several scenarios are generated to analyze the system in depth.

\subsection{Literature Review}

Currently, there are a few studies on long-distance power transmission between Australia and Asia. Halawa et al. [15] discussed benefits and challenges of an AustralianAsian power grid reviewing various scenarios presented in the literature. An Asia-Pacific supergrid used to supply Southeast Asia with electricity from Australia was analyzed in [16]. More recently, Lu et al. [17] discussed and analyzed the role of short-term offriver energy storage for higher penetration of renewable energy (as much as $97 \%$ ) in the Asia-Pacific supergrid delivering substantial environmental benefits. Wang et al. [18] performed a case study on the economic viability of a transmission network in Australasia. It suggested to connect Australia's Northern Territory to Indonesia via a subsea HVDC cable and to Queensland, Australia, via a ground HVDC cable. Itiki et al. [19] presented a study on a HVDC interconnection between Japan, Taiwan, and the Philippines with the possibility of connecting it to a proposed interconnector between Australia, Indonesia, and the Philippines. Emissions were not considered in that study. Gulagi et al. [20] performed a cost optimization of a fully renewable energy system for Southeast Asia and the Pacific Rim. The authors analyzed the costs of the system, but not its emissions. Similar studies exist for other parts of the world, too. For example, scenarios for cost-optimal deployment of an HVDC interconnection between North Africa and Europe were presented in [21]. The core of the above-mentioned studies were techno-economic assessment and feasibility studies. However, none of them included life cycle assessment (LCA) for analyzing the emissions of long-distance power transmission.

There are only few studies on LCA of long-distance HVDC transmission systems. However, to the best of our knowledge, none were published in recent years. Jorge et al. [22] presented a life cycle inventory (LCI) of power lines and cables. The authors collected data from a utility company and calculated the emissions of a subsea HVDC cable to be $130 \mathrm{tCO}_{2}$ eq. A hybrid LCA of an offshore grid in the North Sea was performed in [23]. The resulting emissions of the cables were $215 \mathrm{tCO}_{2} \mathrm{eq} / \mathrm{km}$ with $117 \mathrm{tCO}_{2} \mathrm{eq} / \mathrm{km}$ generated in the physical subsystem, which includes electricity generation, transport, metal extraction and processing, and others.

There are a few other recent studies that performed LCA of power transmission that include other system components, such as the work by Harrison et al. [24] assessing the power system of Great Britain, Jorge and Hertwich [25] analyzing the power transmission system 
of Norway, Kiss et al. [26] studying the Hungarian power system, and Orfanos et al. [27] evaluating the Greek power system. While these studies included power transmission, they did not include long-distance HVDC transmission systems. Moreover, none of the studies that include LCA of power transmission has been carried out within the geographic horizon of Asia or Australia.

Lack of recent work that studies the emissions of long-distance electricity transport in the Australasian region prompted us to develop an indigenous methodology to analyze the environmental impacts of importing solar electricity from Australia into Singapore using subsea HVDC cables.

\subsection{Contribution of This Paper}

This paper provides new insights into the combination of energy system models and LCA to determine the emission balance of a long-distance power transmission. We first developed a cost optimization model to determine the cost-optimal sizing of a subsea HVDC cable, solar PV power plant installation, and batteries. Next, we developed a comprehensive parameterized LCA model to determine the specific emissions of the components. The combination of the cost optimization model and LCA models including all components and life cycle stages, which is the key contribution of this work, allows for estimating the potential environmental impacts and benefits of a long-distance HVDC connection to transmit solar energy from Australia to Singapore. Finally, we created multiple scenarios by varying the parameters of the cost optimization and LCA models to understand the in-depth costs and emissions of long-distance solar PV electricity transport. This also allows us to identify opportunities to improve the environmental performance of such a system further.

The rest of the paper is organized as follows. Materials and methods are presented in Section 2, which is broken down further into two subsections. Section 2.1 presents the methods used in order to achieve the results, namely the development of the cost optimization model and the LCA model, and the combination of both. In Subsection 2.2, the data gathered for this study are presented. Various scenarios, a sensitivity analysis, and the results of these are introduced in Section 3. The paper is concluded in Section 4.

\section{Materials and Methods}

\subsection{Methods}

The primary aim of this work is to estimate the $\mathrm{CO}_{2}$ emissions of electricity import to Singapore along the whole supply chain. The design of the system is loosely based on the Sun Cable project, which is chosen as the starting point for this evaluation. To assess the emissions of renewable energy import, this work is divided into two phases. The first phase defines the capacities of the system components via a cost optimization model. The second phase analyzes the specific emissions of the system throughout its lifetime. Next, we explain the workflow followed in this study and how the methods are applied.

\subsubsection{Workflow}

Figure 1 is a graphical representation of the inputs and outputs of the cost optimization model urbs [28] and the LCA model, and describes how they interact. The optimization model provides the cost-optimal capacities of the different components of the system in order to cover $20 \%$ of the annual electricity demand of Singapore. The model takes into account several techno-economic parameters, such as the solar PV potential output, technology and fuel costs, and the cable length. It then computes the total amount of electricity generated in Australia within a year and the different losses along its pathway to Singapore. In combination with assumptions on the lifetime of the project and its individual components, we can estimate the total energy generated and the total capacity of each component required over the lifetime of the project. 
To conduct the LCA, we developed a parameterized model to enable the analysis of numerous alternative scenarios. Each component of the system (PV panels, storage system, cable) was modeled in detail (see Section 2.2).

By combining the specific upstream emissions evaluated by the LCA model and the capacities from the urbs model, we are able to evaluate the specific emissions of the electricity produced by the entire project over its lifetime.

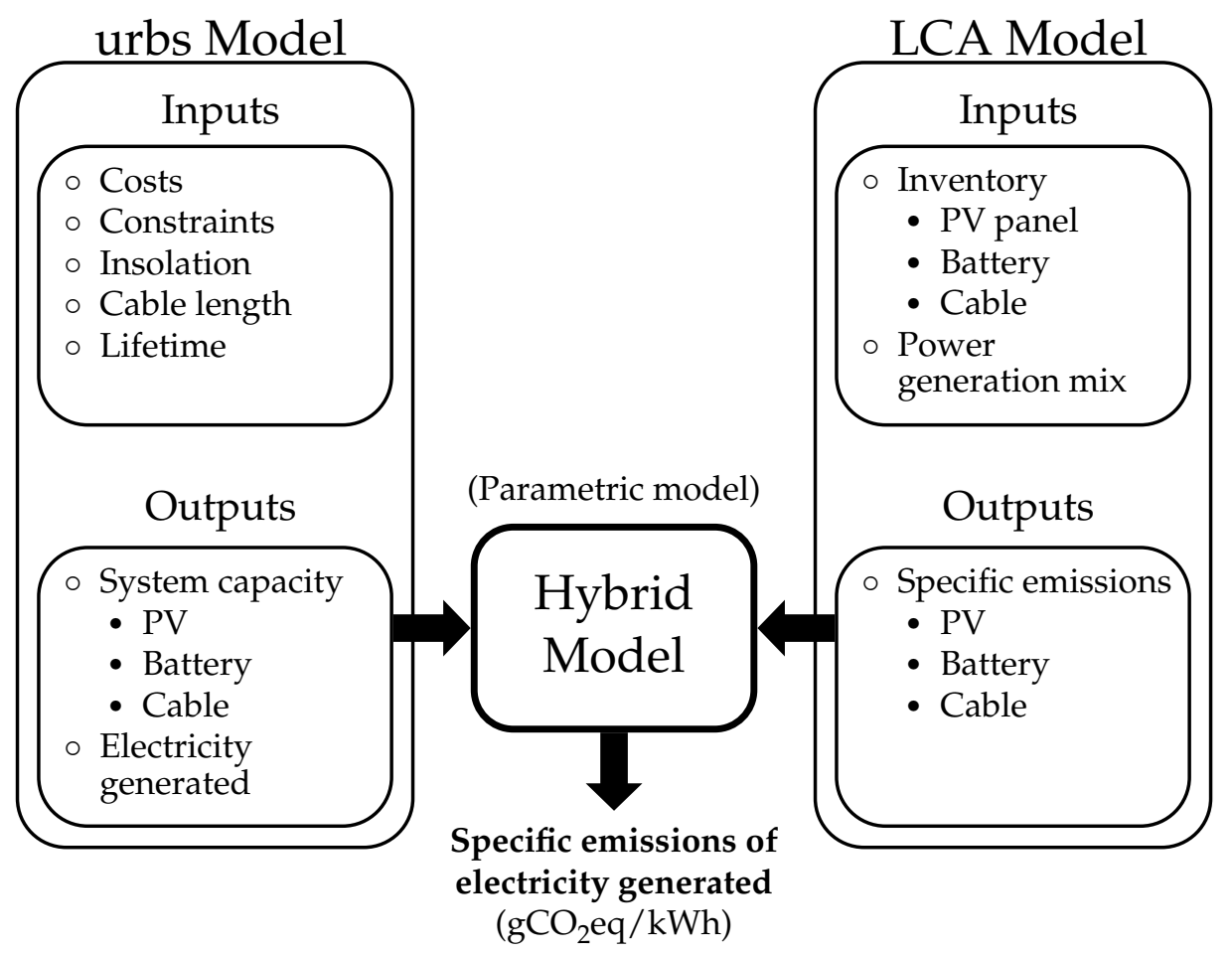

Figure 1. urbs-LCA Interaction.

\subsubsection{Cost Optimization with urbs}

The cost optimization model connecting Australia and Singapore was developed using the open-source modeling framework urbs. The model co-optimizes capacity expansion as well as hourly dispatch of generation, transmission, and storage from a social planner perspective. The objective is to minimize the costs of expanding and operating the energy system, which include the annualized investment costs, fuel costs, fixed and variable operation and maintenance costs, and environmental costs. It solves a linear optimization problem that is written in Python/Pyomo using Gurobi. The source code for urbs and an extensive documentation can be found on GitHub [28]. The exact branch for this paper, including inputs and outputs, is also referenced [29].

The developed model has an hourly temporal resolution and models the years 2019 and 2030. Regarding the level of spatial detail, three model regions are used: Tennant Creek (where the solar PV will be installed), Darwin (where the subsea cable connection starts), and Singapore. The 2019 model does not include the subsea cable connection. It is merely used for calibration in order to reproduce Singapore's present power generation mix. For 2030, we extrapolate the power demand of Singapore at a yearly growth rate of $2 \%$ (similar to the average growth rate between 2011 and 2019 [30]), keep the existing power plant capacities unaffected (i.e., decommissioned power plants are replaced with similar ones with the same capacity), allow for the installation of solar PV plants, battery storage systems and transmission lines, and set a minimum constraint of $20 \%$ electricity imports from Australia. The purpose of the 2030 optimization is to determine the cost-optimal capacities of the solar PV plant, the battery system, and the HVDC cable needed to fulfill the import constraint. 


\subsubsection{Life Cycle Assessment}

Life cycle assessment is a standardized method to evaluate the potential environmental impacts of products and services considering all stages along their life cycle [31,32]. In LCA, all inputs and outputs in terms of energy, resources, co-products, emissions, and wastes are accounted for along the whole supply chain. Later, they are translated into impacts by applying different impact assessment methods.

In our study, the goal is to assess the potential environmental impacts associated with the generation of electricity in Australia by solar PV and its transmission to Singapore through a HVDC cable, and to identify opportunities to improve the system. The main function of the system is to generate and transmit electricity to Singapore. Therefore, the functional unit is defined as $1 \mathrm{kWh}$ of electricity delivered to Singapore. The temporal horizon is 2019 and the geographical horizon is Australia and Singapore, although other regions worldwide are indirectly involved.

The analysis follows a cradle-to-gate approach. All upstream processes are included in the analysis until the electricity reaches Singapore. The dismantling and decommissioning operations of the system components are therefore outside the system boundary. End-oflife application/treatment methods for the system components are left beyond the scope of this work due to insufficient data. A screening LCA quickly assesses the environmental impacts of all the sub components of a system to help identify the critical ones. This allows the LCA practitioner to model critical components in detail while neglecting the trivial ones. Such a screening LCA carried out at the early stage of this study suggested that solar PV power plant, the storage system and the HVDC cable contribute the highest. The screening LCA also revealed that the environmental impacts of auxiliary elements, such as HVDC converter stations, transformers, and substations (based on the data from $[23,33,34]$ ) are negligible. Hence, we excluded them from this study. Figure 2 shows the main processes within the system boundaries.

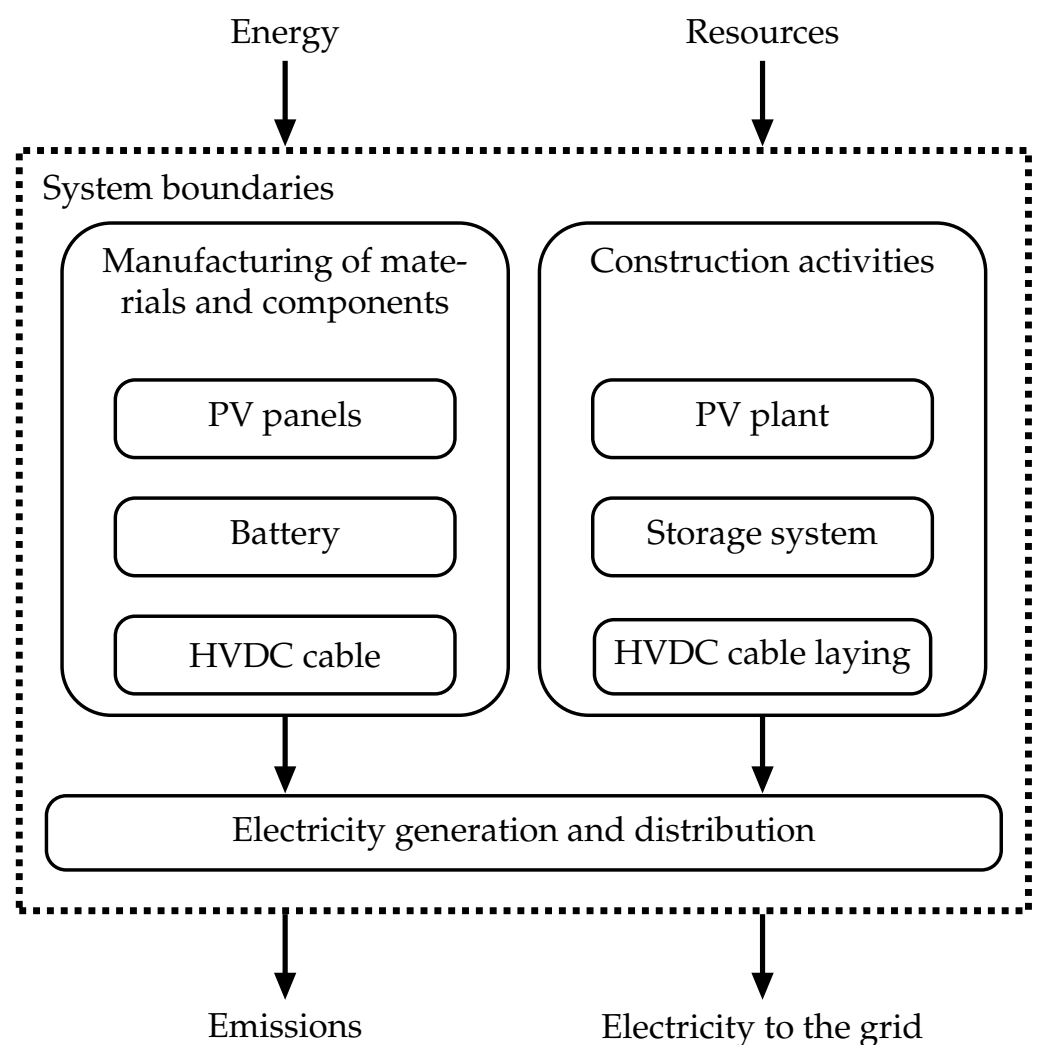

Figure 2. System boundaries. 
The LCA analyzes the reference scenario based on the outputs of the urbs model. The optimization model provides the technical characteristics of the primary components (capacity, lifetime, full-load hours (FLH), etc.), which are used as primary data to build the LCI. As background data, we use the life cycle database ecoinvent v3.7 [33]. Once the life cycle impact assessment is carried out for the reference scenario, other alternative scenarios are explored to identify potential measures to minimize the environmental impacts.

As stated in the introduction, the motivation behind this project is the reduction of the carbon intensity of Singapore to comply with the targets of the Paris Agreement. For this reason, we focus only on the global warming potential as the main environmental impact. The IPCC 2013 impact assessment method was chosen to calculate the global warming potential [35], since it is the most accepted and recommended method in LCA. The model used in this method relates the radiative forcing of different substances with the climate response. In this method, each greenhouse gas has a global warming potential, which indicates the radiative forcing caused by an emission of a unit mass of a given substance, accumulated in the atmosphere during a given time horizon, in relation to $\mathrm{CO}_{2}$.

\subsection{Data}

\subsubsection{Data for the urbs Model}

The developed model uses information about the electricity generation capacity by generator [36] and the half-hourly electricity demand [37] for the year 2019, which is made available under the terms of the Singapore Open Data Licence version 1.0 (https: / / www.ema.gov.sg/Terms_of_use.aspx, accessed on 19 February 2021). We aggregate the half-hourly demand data to obtain hourly time series for 2019, then extrapolate it until 2030. The extrapolation consists of scaling up the time series using a yearly electricity demand growth rate of $2 \%$, which corresponds to the average growth rate in Singapore between 2011 and 2019 [30].

Additional parameters for the existing power plants regarding their efficiencies and costs are obtained from the ETRI 2014 report [38]. To calibrate the model, we set the minimum fraction of each power plant in such a way that the generation mix matches historical data of 2019. For 2030, we assume that the same power plants still exist and that new ones can be built using cost assumptions from the ETRI 2014 report [38]. Battery storage system cost assumptions are retrieved from the same report, whereas transmission line costs are broadly based on Lauria et al. [39]. We use a conversion rate of EUR 1.0 to USD 1.1. Commodity prices for oil and gas are obtained from the World Energy Outlook 2019 [40] and we assume that they remain unchanged in the future. Major techno-economic parameters can be found in Table A1 in Appendix A, whereas all input data and scripts can be retrieved following the link in the Data Availability section.

Time series for solar PV output in Singapore and Tennant Creek, Northern Territory, Australia are generated using pyGRETA [41] together with weather data for 2015, assuming state-of-the-art module characteristics from the REC alpha series (REC380AA) [42].

One major model constraint that forces the model to build solar PV in Australia and export solar energy to Singapore is that the cable should supply $20 \%$ of the electricity demand of Singapore. Moreover, the ramping requirement at the entry point to the Singaporean grid should not exceed $500 \mathrm{MW}$ per hour, which is equivalent to the capacity of a typical large natural gas combined cycle gas turbine (CCGT) power plant. While the battery system in Tennant Creek manages balancing solar fluctuations, this additional constraint ensures that the urbs model does not change the power transmitted through the cable by more than $500 \mathrm{MW}$ within an hour. This enables the local power plants to ramp up or down in time to balance the hourly fluctuations of the cable output power. The current model does not take into account disruptions that could cause a cable rupture, such as seismic events. If these events were to be considered in the planning, there should be additional storage capacity at each end of the cable to act as a reserve in case of emergency. 


\subsubsection{Life Cycle Inventory}

The analyzed system is composed of three main elements: (i) the battery storage system; (ii) the PV power plant; and (iii) the subsea HVDC cable. Some assumptions have been made in order to complete the LCI of our study.

The storage system comprises lithium-ion batteries with an estimated lifetime of ten years. The battery has three main components: the cells, the module, and the pack. The production of the pack and modules is quite standardized, mainly involving aluminum, copper, and steel as raw materials. On the contrary, the cells are very specific in each battery. We based our model on the materials and quantities described by [43] but assuming manufacturing to be located in Australia; therefore, utilizing Australian electricity [44]. The heat required for the manufacturing process is assumed to be produced from natural gas. Table 1 shows the components and materials of the battery storage system.

Table 1. Materials and energy needed for battery storage system production per $\mathrm{kWh}$ (data retrieved from [43]).

\begin{tabular}{|c|c|c|}
\hline Component & Material & Amount (g/kWh) \\
\hline \multirow[t]{12}{*}{ Cell } & NMC11 powder & 1800 \\
\hline & Graphite & 990 \\
\hline & Carbon black & 120 \\
\hline & Binder & 150 \\
\hline & Copper & 800 \\
\hline & Aluminum & 420 \\
\hline & Electrolyte: LiPF6 & 110 \\
\hline & Electrolyte: ED & 320 \\
\hline & Electrolyte: DMC & 320 \\
\hline & Polypropylene & 77 \\
\hline & Polyethylene & 18 \\
\hline & Polyethylene terephthalate & 14 \\
\hline \multirow[t]{5}{*}{ Module } & Copper & 18 \\
\hline & Aluminum & 310 \\
\hline & Polypropylene & 8 \\
\hline & Insulation & 5 \\
\hline & Electronic parts & 48 \\
\hline \multirow[t]{6}{*}{ Pack } & Copper & 4 \\
\hline & Aluminum & 950 \\
\hline & Steel & 43 \\
\hline & Insulation & 29 \\
\hline & Coolant & 300 \\
\hline & Electronic parts & 210 \\
\hline Component & Process & Amount (MJ/kWh) \\
\hline \multirow[t]{2}{*}{ Cell } & Heat & 140 \\
\hline & Electricity & 30 \\
\hline
\end{tabular}

The PV power plant consists of multi-silicon (multi-crystalline) PV panels. While most modern panels are made of single crystal passivated emitter and rear contact panels, we chose multi-crystalline panels to represent our PV plant as very high quality LCI is available for the same (from ecoinvent). Models on single silicon PV panels for large scale PV installation are not available in ecoinvent. However, studies have already shown that these do not significantly differ in life cycle GHG emissions [45]. The installed capacity of the plant and the FLH are defined by the urbs model output. The lifetime of the plant is expected to be 25 years. Data available in ecoinvent for the production of panels were used. However, to be consistent with the geographical and temporal horizon, the electricity used 
for panel production was modified to the 2019 Australian electricity mix, as the panels were assumed to be produced in Australia.

The cable is one of the main components of this project because of its dimension and capacity, and due to the lack of previous analyses. In this study, a 3800-km-long subsea HVDC power cable is considered. The life span is expected to be 40 years [46]. The cable conductor material is copper and is covered by an insulation layer comprising impregnated paper (IP) with high-voltage grade impregnation and cross-linked polyethylene. The waterblocking sheath consists mainly of a lead layer. To ensure tension-stability and mechanical protection, the cable is covered with a galvanized steel armor, and finally protected with a polypropylene sheath [47]. In the absence of an exact route, we did not consider obstacles, such as deep-sea trenches, which would lead to higher costs and material demand for small sections of the cable.

Since multiple data sources were available on HVDC cables, we decided to create multiple models and take an average of these values for the final model. Birkeland [34], May [48] and ABB [49] provide the material inventories required per kilometer for different cable capacities. We calculate the emissions of the cable per MW $\mathrm{km}$ using these inventories. To account for the cable manufacturing process, transport, laying activities and maintenance, we used the emission factors derived from an input-output analysis, which was hybridized with process-based LCA [34]. Table 2 shows the different data sources used to build the inventory and the data used in our study. The above mentioned three models are tagged with the term "Calc." to denote that their values were calculated in this study. In addition, Arvesen et al. [23] and Birkeland [34] also provide data on total GHG per MW km. These values are denoted by the tag "Lit." in Table 2 to denote that they are taken from the literature. In summary, we have five values of GHG per MW km from which we calculated the average value to obtain our final emissions associated with the HVDC cable.

Table 2. Life cycle inventory of $1 \mathrm{MW}$ km HVDC cable.

\begin{tabular}{|c|c|c|c|}
\hline Source & Material & $\begin{array}{c}\text { Quantity } \\
\text { (kg/MW km) }\end{array}$ & $\begin{array}{c}\text { Emissions } \\
\left(\mathrm{kg} \mathrm{CO}{ }_{2} \mathrm{eq} / \mathrm{MW} \mathrm{km)}\right)\end{array}$ \\
\hline Arvesen [23]-Lit. & & & 310 \\
\hline Birkeland [34]— Lit. & & & 210 \\
\hline \multirow{6}{*}{ May [48]—Calc. } & Copper & 15.0 & \multirow{6}{*}{250} \\
\hline & IP & 5.6 & \\
\hline & Lead & 14.0 & \\
\hline & Polypropylene & 0.84 & \\
\hline & Steel & 19.0 & \\
\hline & XPLE & - & \\
\hline \multirow{6}{*}{ ABB [49]—Calc. } & Copper & 22.0 & \multirow{6}{*}{250} \\
\hline & IP & - & \\
\hline & Lead & 11.0 & \\
\hline & Polypropylene & 2.2 & \\
\hline & Steel & 11.0 & \\
\hline & XPLE & 5.7 & \\
\hline \multirow{6}{*}{$\begin{array}{l}\text { Birkeland [34]—- } \\
\text { Calc. }\end{array}$} & Copper & 19.0 & \multirow{6}{*}{340} \\
\hline & IP & 7.9 & \\
\hline & Lead & 33.0 & \\
\hline & Polypropylene & 4.3 & \\
\hline & Steel & 4.3 & \\
\hline & XPLE & - & \\
\hline \multicolumn{3}{|l|}{ Our study } & 270 \\
\hline
\end{tabular}




\section{Scenarios and Results}

\subsection{Scenarios}

\subsubsection{Reference Scenario}

The reference scenario for the urbs model consists of a solar PV power plant in Tennant Creek, Australia, connected by a 1000-km HVDC overhead line to Darwin, Australia, where a utility-scale battery storage system is built. Then a 3800-km subsea HVDC cable starts in Darwin and ends in Singapore. According to pyGRETA [41], the PV technical potential in Tennant Creek at a module level is $2100 \mathrm{kWh} / \mathrm{kW}_{\mathrm{p}}$ using 2015 weather data [50] (weather data for 2015 were used because the data were readily available for the globe. It was used for future years because pyGRETA is not able to make weather forecasts or climate change projections). The technical assumptions are based on the REC alpha series (REC380AA) [42]. We assume an efficiency loss of $25 \%$, which includes losses from panel soiling, DC / AC and AC/DC conversion, transformers, and shading. The effective FLH value for the reference scenario is $\mathrm{FLH}_{\text {ref }} \approx 1600 \mathrm{kWh} / \mathrm{kW}_{\mathrm{p}}$. The cable losses are modeled and included separately.

\subsubsection{Scenarios in the LCA Model}

The choice of the processes that correspond to the LCI in the LCA model has a considerable impact on the final emissions. For example, using electricity from lignite to produce batteries would cause much higher emissions than use of electricity from nuclear power. To study this, various scenarios were created by varying the processes. The processes varied for this study can be broadly listed under electricity mix, heat source, metals, and cable models. The following scenarios are not created to replicate different applications for Australia, but rather to understand the impact of different processes on the final emissions.

\section{Electricity Mix}

To consider the impact of the electricity mix on the specific emissions of the components, electricity from lignite (most emissive) and electricity from nuclear energy (least emissive) are considered, along with the standard Australian power generation mix which is a combination of fossil fuels $(\approx 85 \%$, primarily coal) and renewable energy sources $(\approx 15 \%$, with primary contributions from hydro, wind and PV). While nuclear electricity might not have grown globally in the recent past, and Australia might not possess any of it presently, it was chosen to build the scenario as it has the lowest emission intensity amongst the electricity sources (even lower than most renewable energy sources).

\section{Heat Source}

The mechanism of heat production may influence the overall emissions of battery storage system manufacturing. Hence, different sources of heat, namely natural gas, oil, and a heat pump driven by electricity are considered.

\section{Metals}

Steel, copper, and aluminum constitute a big portion of the components. The process by which these metals are sourced influences the specific emissions of the components. While market processes are chosen for the reference scenario, other processes are picked to create additional scenarios. For example, aluminum could be produced from raw ore, which is referred to as primary $(\mathrm{P})$ aluminum, or could be procured by recycling scrap aluminum, which is referred to as recycled $(\mathrm{R})$ aluminum.

\section{Cable Models}

As described in Section 2.2.2, in the literature, there are multiple models for evaluating cable emissions. To comprehend how different cable models impact overall emissions, several scenarios are developed with these models. 


\subsubsection{Scenarios in the urbs Model}

For this analysis, we focus on the impact of the effective solar potential and the length of the subsea HVDC cable to Singapore. Hence, we run the cost-optimization of the system for 49 different combinations of these two parameters:

- Effective solar potential: variation in steps of $10 \%$ between $\mathrm{FLH}_{\text {ref }}-30 \%$ and $\mathrm{FLH}_{\text {ref }}+$ $30 \%$;

- Cable length: variation between 0 and $5000 \mathrm{~km}$ in steps of $1000 \mathrm{~km}$, in addition to the reference length of $3800 \mathrm{~km}$.

When varying the effective solar potential, the magnitude of the PV output time series is scaled up or down with a constant factor. This does not affect the temporal fluctuation of peaks and troughs. Neither does the variation of the cable length, which only affects the cable's efficiency and costs.

\subsection{Results}

\subsubsection{Reference Scenario}

The sizing of the system components is determined through the energy system cost minimization in urbs, which yields the configuration in Table 3 . The energy flows and the losses along the way from Tennant Creek to Singapore for the reference scenario are plotted as a Sankey diagram and can be found in Figure A1 in Appendix A. The hourly load and annual load duration curves can be found in Figures A2 and A3 in Appendix A.

The specific emissions of the components are determined by the LCA models as described in Section 2.1.3. The resulting specific emissions of the components and the total emissions are as follows:

- Battery storage system:

$$
\begin{aligned}
& 97 \mathrm{~kg} \mathrm{CO}{ }_{2} \mathrm{eq} / \mathrm{kWh} \\
& 2330 \mathrm{~kg} \mathrm{CO}_{2} \mathrm{eq} / \mathrm{kW}_{\mathrm{p}} \\
& 270 \mathrm{~kg} \mathrm{CO} 2 \mathrm{eq} / \mathrm{MW} \mathrm{km} \\
& 110 \mathrm{~g} \mathrm{CO}_{2} \mathrm{eq} / \mathrm{kWh}
\end{aligned}
$$

- Cable:

Table 3. Size of system components according to $u r b s$ for the reference scenario.

\begin{tabular}{lrl}
\hline Component & Size & Unit \\
\hline PV capacity in Tennant Creek & 13.0 & GW \\
Overhead HVDC line Tennant Creek—Darwin & 6.1 & GW \\
Subsea HVDC cable Darwin-Singapore & 3.2 & GW \\
Battery storage capacity in Darwin & 17.0 & GWh \\
Battery storage charging capacity & 2.6 & GW \\
\hline
\end{tabular}

Combining the urbs model and the LCA model, the specific emissions of solar electricity import to Singapore are found to be $110 \mathrm{~g} \mathrm{CO}_{2} \mathrm{eq} / \mathrm{kWh}$. The major portion $\left(91 \mathrm{~g} \mathrm{CO}_{2} \mathrm{eq} / \mathrm{kWh}\right.$ ) comes from the PV panels. The second biggest contributor is the battery storage system $\left(13 \mathrm{gCO}_{2} \mathrm{eq} / \mathrm{kWh}\right)$. The fact that batteries need to be replaced every ten years causes this high value. The cable contributes least $\left(6 \mathrm{~g} \mathrm{CO}_{2} \mathrm{eq} / \mathrm{kWh}\right)$.

The emissions of importing solar electricity into Singapore from Australia are just a fourth of electricity from natural gas CCGT plants (the major source of electricity in Singapore). If Singapore imported a fifth of its electricity needs through this project, the total annual emission savings would be $4.3 \mathrm{MtCO}_{2}$ eq. If we ignored the embedded emissions and accounted only for direct emissions, then the savings would be $5.2 \mathrm{MtCO}_{2}$ eq. This is about $10 \%$ of the current annual GHG emissions of Singapore. In comparison, the projections in [4] suggest that the maximum emission reduction from local solar PV is only 3.4 Mt by 2050. 


\subsubsection{Scenarios in the LCA Model}

While scenarios are created by changing the electricity mix, heat source, metals, and cable models, the results are presented under three components, namely PV panels, battery storage system, and cable. The impact of each parameter on the specific emissions of the three components, and in turn the system, is discussed. It needs to be noted that, while the scenarios are created with one component, the other two components are maintained as reference.

\section{Battery Storage System}

Aluminum, electricity, and heat are the major contributors toward GHG emissions from the battery storage system (see Figure A4 in Appendix A). Recycled aluminum can reduce the emissions of battery manufacturing by $20 \%$ as compared to reference scenario. Choosing low-carbon nuclear electricity could reduce battery manufacturing emissions by $18 \%$, whereas high-carbon lignite electricity would increase it by $10 \%$. The choice of heat source does not influence emissions greatly. It is also important to note that changes in emissions of battery storage system production have little influence on the final emissions of electricity generation of the project. These results are tabulated in Table A2 in Appendix A).

\section{Photovoltaics}

For the PV panels, only the influence of change of electricity mix on the manufacturing of the panels is studied. The results of specific emissions of PV panels for the different energy mixes are given in Table 4 . The scenarios electricity_nuclear and electricity-lignite refer to the scenarios in which the PV panels are produced using electricity from nuclear energy and lignite, respectively. We see that the source of electricity has a considerable impact on the emissions of PV panel production. If produced with electricity from nuclear power plants, the emissions of PV panel production decrease by $12 \%$ from the reference case. On the other hand, if PV panels are produced using electricity from lignite, the emissions of $\mathrm{PV}$ panel production increase by (7\%, drop-zero-decimal), causing the overall emissions to increase to $120 \mathrm{~g} \mathrm{CO}_{2} \mathrm{eq} / \mathrm{kWh}$. In fact, one of the reasons for the high specific emissions from the PV panels in the reference scenario is that it assumes to use a coal-dominated (as per 2019) Australian electricity mix for its manufacturing. However, Australia has already started to include considerable amounts of renewable electricity in its mix and is also planning to include it in abundance in the future. Most state governments in Australia target renewable energies to contribute at least $40 \%$ to power generation by 2030 [51]. It also needs to be noted that the underlying processes of PV panel production (for instance, solar cell manufacturing, silicon purification, metal manufacturing, etc.) are modeled by existing data sets in ecoinvent, which is representative of the present manufacturing methods. However, in the future, these processes could become a lot more efficient and environmentally friendly. With advancement in technology, future PV panel manufacturing could have much lower emission intensity $\left(\mathrm{kg} \mathrm{CO}_{2} \mathrm{eq} / \mathrm{kW}_{\mathrm{p}}\right)$ than the one calculated in the reference scenario, which would reduce the emissions of solar electricity further.

Table 4. Specific and total emissions for the solar PV scenarios (absolute values and relative difference as compared to the reference scenario).

\begin{tabular}{|c|c|c|c|c|}
\hline \multirow[t]{2}{*}{ Scenario } & \multicolumn{2}{|c|}{$\begin{array}{c}\text { Specific Emissions } \\
\left(\mathrm{kg} \mathrm{CO} \mathrm{CO}_{2} \mathrm{eq} / \mathrm{kW}_{\mathrm{p}}\right)\end{array}$} & \multicolumn{2}{|c|}{$\begin{array}{l}\text { Total Emissions } \\
\left(\mathrm{g} \mathrm{CO}_{2} \mathrm{eq} / \mathrm{kWh}\right)\end{array}$} \\
\hline & Absolute & (Diff.) & Absolute & (Diff.) \\
\hline Reference & 2325 & & 109 & \\
\hline Electricity (nuclear) & 2042 & $(-12.0 \%)$ & 98 & $(-10.0 \%)$ \\
\hline Electricity (lignite) & 2480 & $(6.7 \%)$ & 116 & $(6.4 \%)$ \\
\hline
\end{tabular}


Cable

The contribution of cables to the emissions of the overall project is minimal and, hence, the different scenarios for the cable will not affect the outcome of the project greatly. However, to have a deeper understanding of the LCA of the cable, we created scenarios by considering different cable models from the literature, and by varying the source of the components of the cable in Birkeland's [34] model. The major contributors of emissions of the cable are displayed in Figure A5, and the scenarios developed are summarized in Table A3 in Appendix A.

\subsubsection{Scenarios in the urbs Model}

To understand how the cable distance impacts the emissions of solar electricity import, we changed the length of the HVDC subsea cable while keeping the other aspects constant. Figure 3 shows the impact of the cable length on GHG emissions. The farther from Singapore the location of the PV plant, the higher the emissions. There are two reasons for this. Firstly, the longer cable causes higher emissions in the manufacturing phase. Secondly, the longer the cable, the higher the losses of power transmission. While PV system losses (AC/DC conversion, shading, etc.) are considered constant in our model, the cable losses are modeled to be dependent on the cable's length. Hence, for delivering the same amount of energy to Singapore, we need higher capacities of PV and battery storage, which increases the overall emissions. Hence, options closer to Singapore might offer solutions with lesser environmental burden.

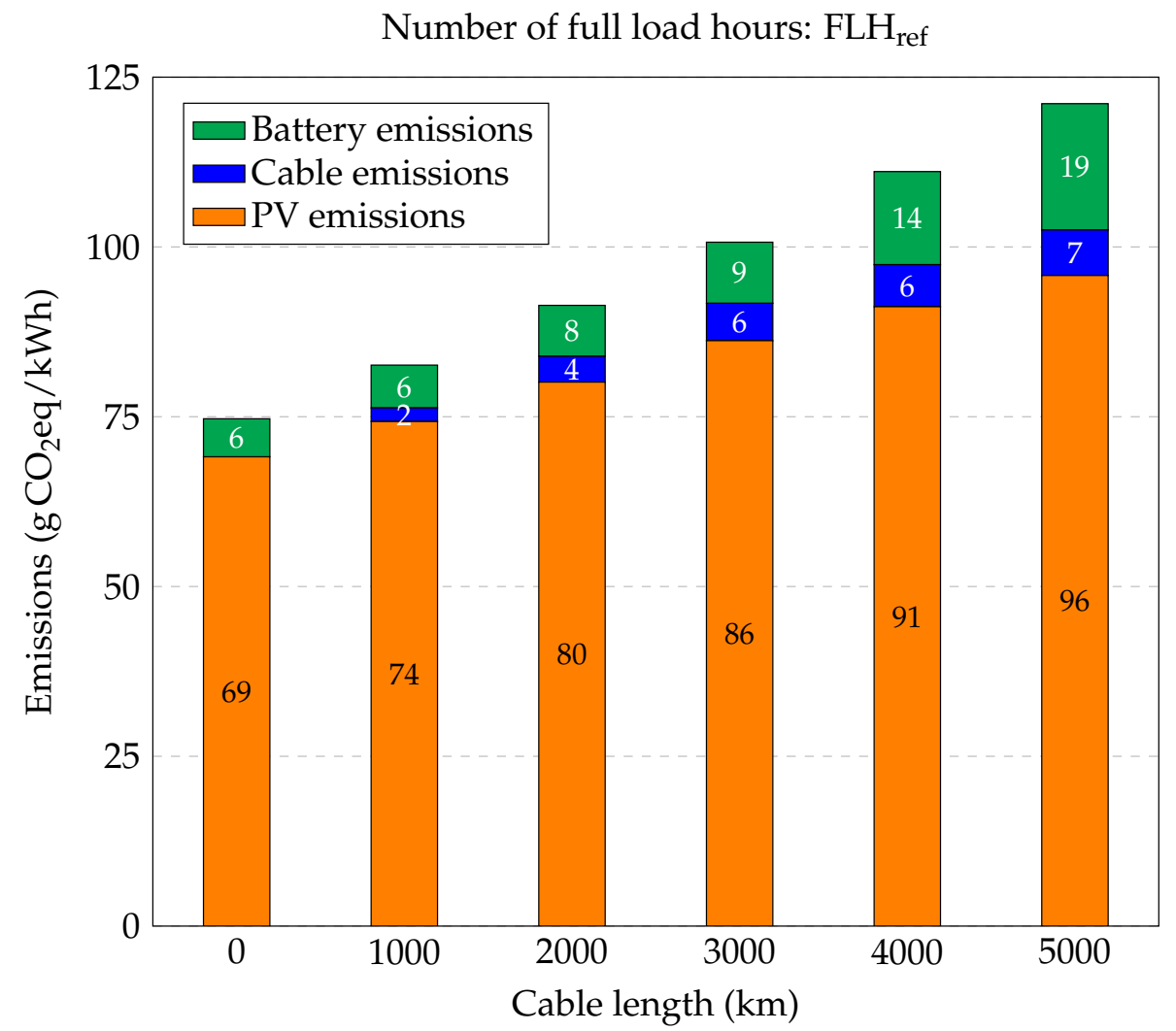

Figure 3. Emissions from production of the battery system, PV installation, and cable per kWh of electricity generated for different cable lengths and reference full-load hours $\left(\mathrm{FLH}_{\mathrm{ref}}\right)$.

If we are to choose locations other than Australia, not just the cable length changes, but also the insolation and, hence, the FLH. The generation profiles also change, but for the sake of simplicity, their effects are neglected in this experiment. The simplification is acceptable because the PV imports do not contribute to the firm generation capacity of Singapore, which has sufficient reserves even if there are no PV imports at all, and which 
relies mainly on gas power plants with similar operating costs. To study the effect of the insolation, we changed the FLH of the PV keeping all other parameters constant. What we observe from Figure 4 is that the higher the FLH, the lower the specific emissions. Hence, high-insolation sites have an obvious advantage in terms of lower emissions of solar energy import.

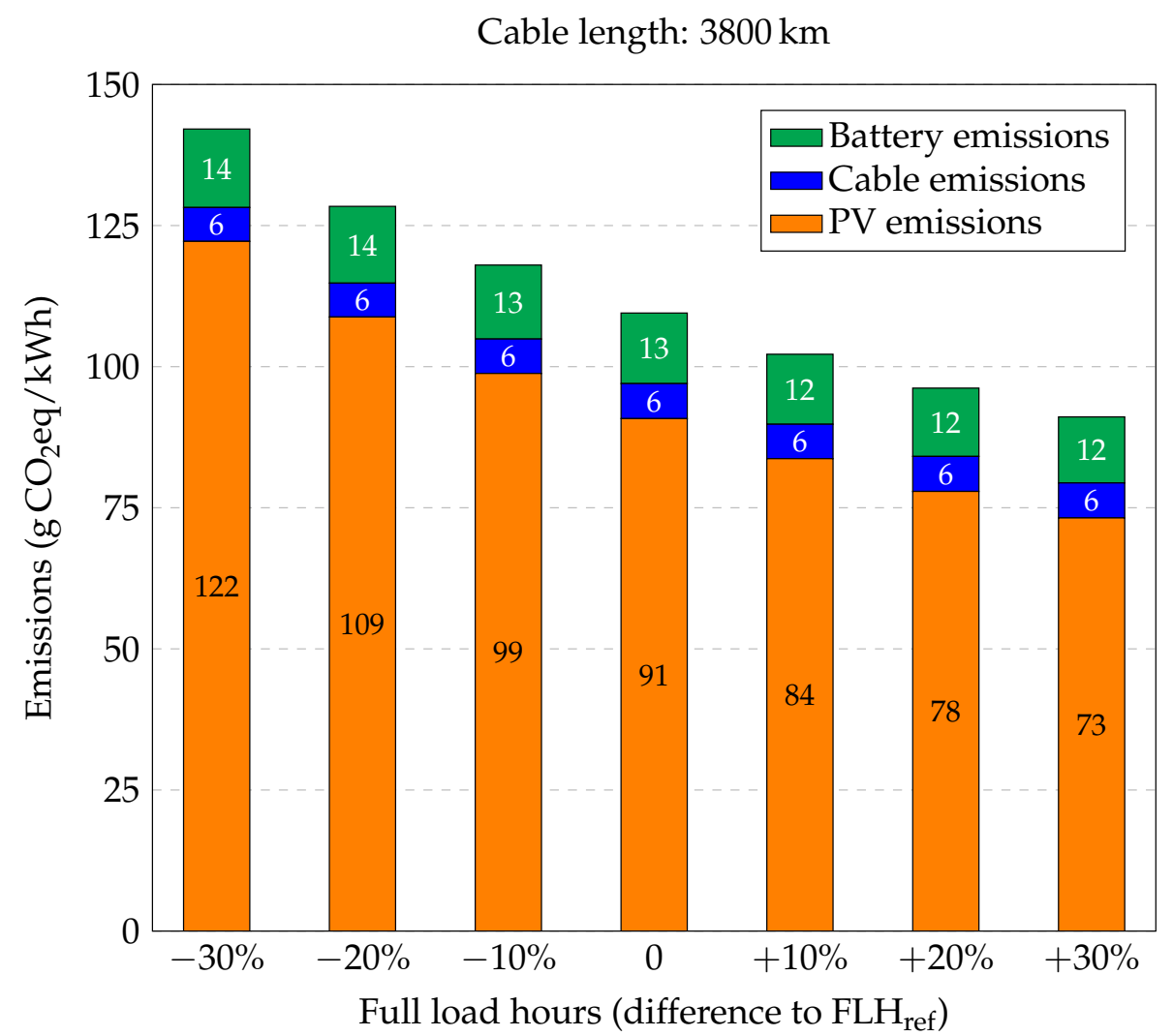

Figure 4. Emissions from production of the battery system, PV installation, and cable per $\mathrm{kWh}$ of electricity generated for different numbers of full-load hours and a cable length of $3800 \mathrm{~km}$.

In the next step, we analyzed the combined effect of changes in cable length and FLH as this would represent different sites of solar PV installation. Figure 5 provides the combined effect of cable length and FLH on specific emissions of the electricity imported. The above-mentioned individual effects of FLH and cable length are visible in these plots. An interesting observation is that we can find break-even values between the two. For instance, if we cap the emission intensity of electricity to $100 \mathrm{gCO}_{2} \mathrm{eq} / \mathrm{kWh}$, this can either be provided by a $3000 \mathrm{~km}$ long cable that has the same number of FLH as that of Australia or by a site that is just $1000 \mathrm{~km}$ away, which has $20 \%$ lower FLH than that of Australia.

However, things are different when seen from the cost perspective. The scatter plot in Figure 6 shows the effect of FLH and cable length on specific emissions and levelized cost of electricity (LCOE). This graph clearly shows that the options that are closer to Singapore offer inexpensive solutions than the ones farther away. The cost of the cable has a huge impact on the overall LCOE, which is not the case for the share of emissions caused by the cable. 


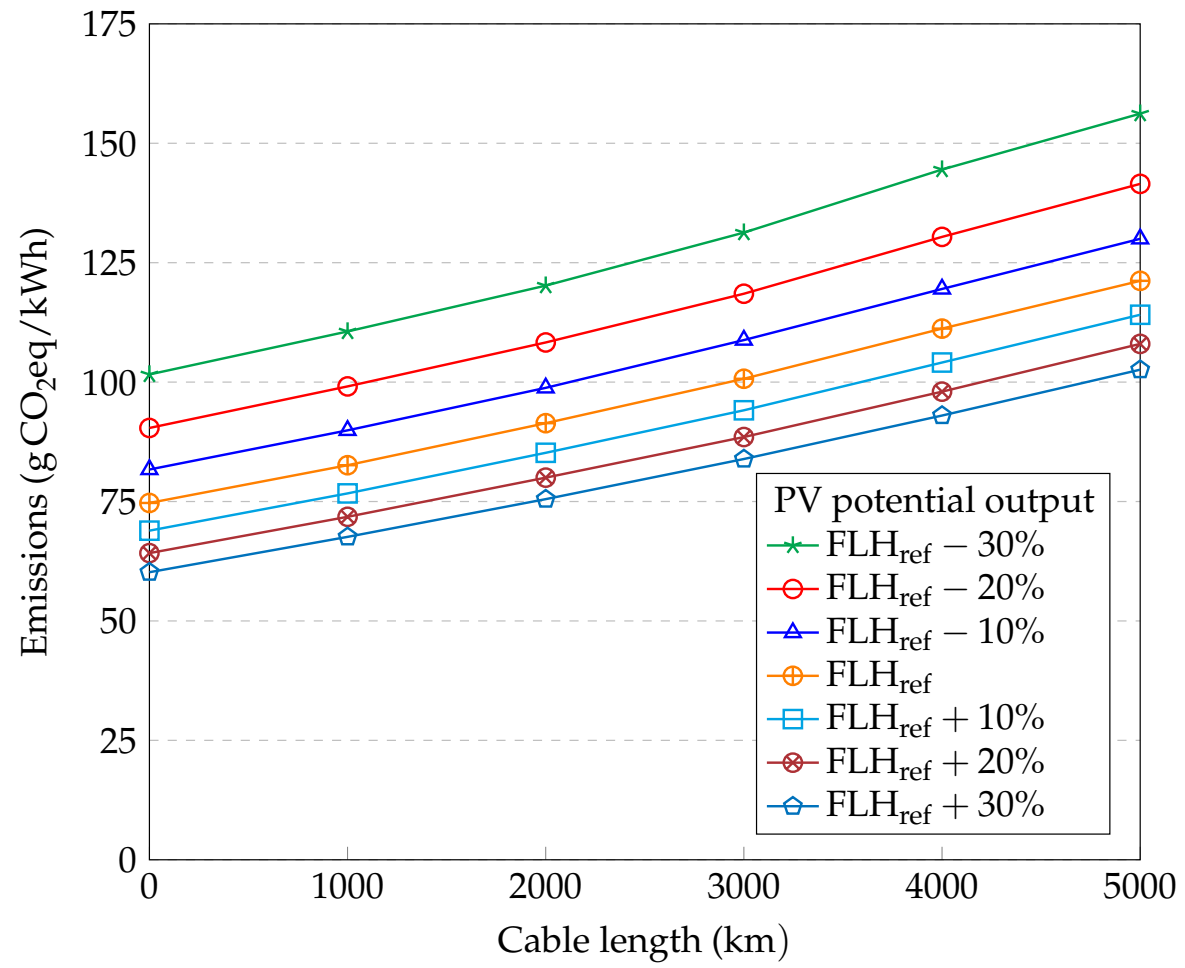

Figure 5. Emissions per kWh of electricity generated for different numbers of full-load hours and different cable lengths.

Full load hours

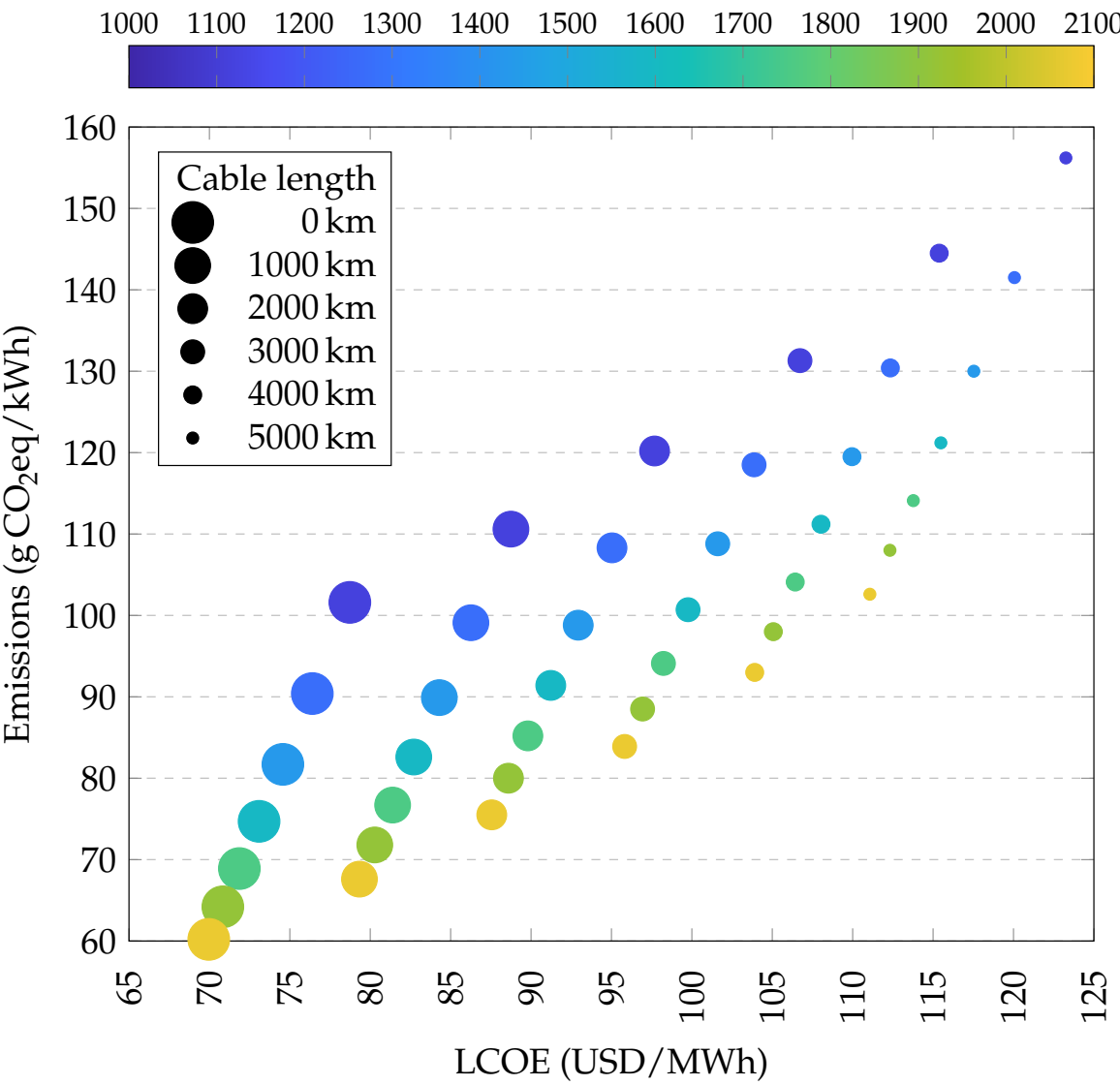

Figure 6. Scatter plot showing specific emissions and LCOE subject to cable length and FLH. 
By performing a regression on the results, a function was created to estimate emissions based on FLH and cable length. Then a database on FLH of different areas surrounding Singapore is generated using pyGRETA [41] and the weather data for 2015, assuming state-of-the-art module characteristics from the REC alpha series [42]. Combining the created function and the FLH data, we obtain the maps in Figure 7 that show the emissions of solar energy import from different regions around Singapore. The maps are consistent with the inference drawn above that regions closer to Singapore can offer options with lower emissions than Australia. Please note that the regression function was derived using the temporal fluctuations specific to the generation profile of Tennant Creek in Australia. We did not use the solar generation profiles of the different regions in order to optimize the system design for each location and to plot the maps.

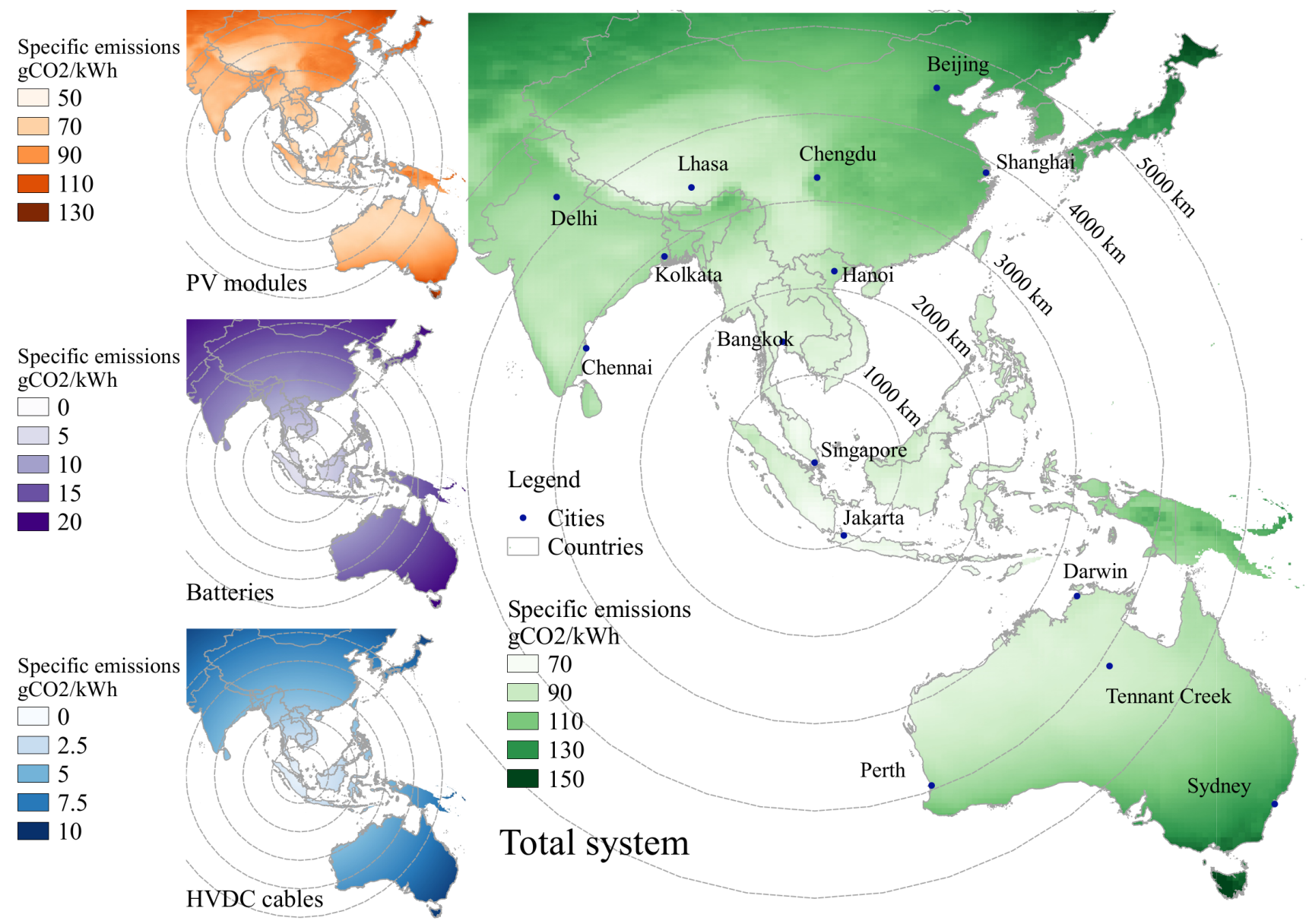

Figure 7. Specific $\mathrm{CO}_{2}$ emissions per unit of electricity imported for the PV modules, battery storage system, and HVDC cable (left) and for the total system (right).

\subsubsection{Impact of Land Use Change}

Considering the specific emissions and costs, there are many options that are geographically closer to Singapore and have similar environmental impact but lower costs than the reference scenario. However, other environmental aspects that can only be assessed on a case-by-case basis have to be considered to get a comprehensive analysis. Hence, we zoom into Jambi in Indonesia, which appears to be a good alternative as it is closer to Singapore, and compare it to our reference scenario.

In the reference scenario, the power plant is located in a desert that does not cause any additional $\mathrm{CO}_{2}$ emissions from land use change (LUC). In the case of Indonesia, $\mathrm{CO}_{2}$ emissions from LUC need to be included since the carbon stock in the vegetation and in soil might influence the final results. The scenario assumes that the PV plant 
and the storage system in Jambi will occupy around $290 \mathrm{~km}^{2}$ of a former oil palm plantation. The calculation of carbon stocks follows the guidelines proposed in Directive 2009/28/EC [52], assuming a tropical wet climate and low-activity clay soil. $\mathrm{CO}_{2}$ emissions from LUC reach $14 \mathrm{~g} \mathrm{CO}_{2} \mathrm{eq} / \mathrm{kWh}$. Specific emissions from PV panels, storage and cable amount to $94 \mathrm{~g} \mathrm{CO}_{2} \mathrm{eq} / \mathrm{kWh}$, which brings the overall system emissions-including LUC - to $108 \mathrm{~g} \mathrm{CO}_{2} \mathrm{eq} / \mathrm{kWh}$. This corresponds to a reduction of approximately $1.3 \%$ only, compared to the reference scenario. A full analysis including the emissions from land use change was outside the scope of this study. Although the above example suggests that the emissions from LUC in the tropical regions of Southeast Asia could significantly offset the environmental benefits of a shorter cable length, the possibility of using other surfaces as support as proposed by Silahali et al. [53], for instance, could also be considered in the region. Floating solar plants could be a good alternative. Recently, a project to supply Singapore with PV power from a floating PV installation near the Indonesian Island of Batam, $50 \mathrm{~km}$ away from Singapore, was announced [54]. Besides avoiding any impact related to changes in land use and the ecosystem around, floating PV can reduce evaporation, which can be essential in same semi-arid regions. However, some researchers suggest that these systems could lead to other potential impacts, such as decrease in water quality, the impact due to shadows in fishes, plants or sediments, although there is not yet much empirical evidence in the long term due to its novelty [55].

\section{Conclusions}

In this paper, the life cycle emissions associated with the import of electricity generated from large scale solar PV panels in Australia into Singapore through a long-distance subsea HVDC connection were estimated. A cost optimization model was developed to determine the optimal size of the system components. The primary constraint was that the system should deliver a fifth of Singapore's electrical energy needs. The capacities of such a system were estimated to be a 13-GW PV power plant, a 17-GWh battery storage system, and a 3.2-GW capacity subsea cable. With our developed LCA model, the specific emissions of the PV panels, the cable and battery system were found to be $2330 \mathrm{gCO}_{2} \mathrm{eq} / \mathrm{kW}_{\mathrm{p}}$, $270 \mathrm{gCO}_{2} \mathrm{eq} / \mathrm{MW} \mathrm{km}$ and $97 \mathrm{~g} \mathrm{CO}_{2} \mathrm{eq} / \mathrm{kWh}$, respectively. By combining the two models, the emissions of electricity generation were estimated to be $110 \mathrm{~g} \mathrm{CO}_{2} \mathrm{eq} / \mathrm{kWh}$.

The majority of the emissions was caused by the manufacturing of the PV panels. In this evaluation, the panels were assumed to be produced using the coal-dominated Australian electricity mix. However, as discussed in Section 3.2.2, Australia is planning to include ample low-carbon renewable energy sources in its electricity mix in the near future, which would reduce the emissions of PV panel manufacturing considerably making solar electricity even more sustainable than it presently is. In general, if the electricity for manufacturing the panels is generated from renewable energy, emissions of PV panel production would drop considerably. This reiterates the importance of including renewable energy in the grid, as it would have a compounded positive impact on future projects. Moreover, the PV manufacturing process could get more environmentally friendly in the future; thus, reducing the emissions of solar electricity. Policy makers could urge PV manufacturing industries to look in this direction.

The second major contribution of the emissions came from the battery system. In this publication, new batteries were assumed to be used. However, for reducing the carbon footprint of large-scale renewable energy applications, used batteries with a second-life application along with battery recycling methods can be considered.

The cable contributes least to the emissions. This is owing to its long lifetime and the large amount of electricity transported over its lifetime. However, this does not mean that long-distance subsea cables are silver bullets to the climate change issue, as they are associated with high costs and a complex laying process. Nevertheless, a good observation is that cables are more of a technical/economic bottleneck for such projects, but are light on their carbon footprint. 
It needs to be noted that this publication is focused on GHG emissions only. Other environmental aspects, such as toxicity, acidification, resource depletion, etc., should be considered to make an informed decision. This, however, was beyond the scope of this publication.

To understand the contribution of different metals and the electricity mix toward emissions, different scenarios were generated in the LCA model. The general observation was that the use of low-carbon electricity (for manufacturing) and recycled materials reduced the specific emissions of the components considerably. The importance of recycling and low-carbon energy was further established here.

We created further scenarios by changing the FLH of the PV panels and length of the cable to understand their combined effect. We observed that sites closer to Singapore were able to provide electricity at similar or lower GHG emissions (as compared to Australia) in spite of lower insolation. The lower cost of shorter cable lengths should encourage policy makers to look for sites much closer to Singapore. However, as opposed to the deserts of Australia, regions closer to Singapore are covered by vegetation. Thus, LUC could contribute significantly toward emissions and, hence, site selection plays a crucial part.

Author Contributions: S.R.: conceptualization, methodology, formal analysis, writing-original draft, visualization. K.S.: methodology, formal analysis, writing-original draft, visualization. C.d.L.R.: supervision, validation, writing-review and editing. T.M.: supervision, validation, visualization, writing—review and editing. A.A.: validation, writing-review and editing. T.H.: validation, supervision. All authors have read and agreed to the published version of the manuscript.

Funding: This work was financially supported by the Singapore National Research Foundation under its Campus for Research Excellence And Technological Enterprise (CREATE) programme.

Institutional Review Board Statement: Not applicable.

Informed Consent Statement: Not applicable.

Data Availability Statement: The urbs branch used for this paper is available at https://doi.org/10 .5281 /zenodo.4486189 (accessed on 26 Augugst 2021).

Conflicts of Interest: The authors declare no conflict of interest.

$\begin{array}{ll}\text { Abbreviations } \\ \text { ASEAN } & \begin{array}{l}\text { Association of Southeast Asian Nations } \\ \text { CCGT }\end{array} \\ \text { combined cycle gas turbine } \\ \text { FLH } & \text { full-load hour } \\ \text { GHG } & \text { greenhouse gas } \\ \text { HVDC } & \text { high-voltage direct current } \\ \text { LCA } & \text { life cycle assessment } \\ \text { LCI } & \text { life cycle inventory } \\ \text { LCOE } & \text { levelized cost of electricity } \\ \text { LUC } & \text { land use change } \\ \text { PV } & \text { photovoltaic }\end{array}$

\section{Appendix A}

Table A1 shows the major techno-economic assumptions of the urbs model. Technology costs for the year 2020 are used because the construction was assumed to start in the first half of this decade, so that operation could start around 2027. The input data and scripts with all assumptions are available in [29]. Tables A2 and A3 show specific and total emissions for the battery storage system and cable scenarios. 
Table A1. Major techno-economic assumptions of the urbs model.

\begin{tabular}{llrl}
\hline Parameter & Unit & Value & Source \\
\hline Weighted Average Cost of Capital & $\%$ & 7 & assumption \\
\hline Solar PV investment costs & USD/MW & 880,000 & {$[38]$} \\
Solar PV fixed O\&M costs & USD/MW & 15,000 & {$[38]$} \\
Solar PV lifetime & years & 25 & {$[38]$} \\
\hline Subsea HVDC cable investment costs & USD/MWkm & 1270 & {$[39]$} \\
Converter station investment costs & USD/MW & 176,000 & {$[39]$} \\
Subsea HVDC cable fixed O\&M costs & USD/MWkm & 23,100 & {$[39]$} \\
Subsea HVDC cable losses & $\% / 1000 \mathrm{~km}$ & 5 & assumption \\
Subsea HVDC cable lifetime & years & 40 & {$[38]$} \\
\hline Battery storage capacity investment costs & USD/MWh & 281,000 & {$[38]$} \\
Battery charging capacity investment costs & USD/MW & 143,000 & {$[38]$} \\
Battery charging fixed O\&M costs & USD/MW & 2000 & {$[38]$} \\
Battery lifetime & years & 10 & {$[38]$} \\
\hline & & &
\end{tabular}

Table A2. Specific and total emissions for the battery storage system scenarios (absolute values and relative difference as compared to the reference scenario). (P) stands for primary material, (R) for recycled material.

\begin{tabular}{lcccc}
\hline \multirow{2}{*}{ Scenario } & \multicolumn{2}{c}{$\begin{array}{c}\text { Specific Emissions } \\
\text { (kg CO }\end{array}$ eq/kW } & \multicolumn{2}{c}{$\begin{array}{c}\text { Total Emissions } \\
\text { (g CO }\end{array}$ eq/kWh) } \\
& Absolute & (Diff.) & Absolute & (Diff.) \\
\hline Reference & 97 & & 109 & \\
Electricity (nuclear) & 80 & $(-17.5 \%)$ & 107 & $(-1.8 \%)$ \\
Electricity (lignite) & 107 & $(10.3 \%)$ & 111 & $(1.8 \%)$ \\
Heat (natural gas) & 97 & $(0.0 \%)$ & 109 & $(0.0 \%)$ \\
Heat (oil) & 101 & $(4.1 \%)$ & 110 & $(0.9 \%)$ \\
Heat (heat pump) & 96 & $(-1.0 \%)$ & 109 & $(0.0 \%)$ \\
Aluminum (R) & 78 & $(-19.6 \%)$ & 107 & $(-1.8 \%)$ \\
Aluminum (P) & 107 & $(10.3 \%)$ & 111 & $(1.8 \%)$ \\
\hline
\end{tabular}

Table A3. Specific and total emissions for the cable scenarios (absolute values and relative difference as compared to the reference scenario). The top half of the table represents the scenarios created by using different cable models. The bottom half of the table represents the scenarios created by varying the source of material in Birkeland's [34] model. (P) stands for primary material, (R) for recycled material.

\begin{tabular}{|c|c|c|c|c|}
\hline \multirow[t]{2}{*}{ Scenario } & \multicolumn{2}{|c|}{$\begin{array}{c}\text { Specific Emissions } \\
\left(\mathrm{kg} \mathrm{CO} \mathrm{CO}_{2} \mathrm{eq} / \mathrm{kW}_{\mathrm{p}}\right)\end{array}$} & \multicolumn{2}{|c|}{$\begin{array}{l}\text { Total Emissions } \\
\text { (g CO } \mathrm{g}_{2} \mathrm{eq} / \mathrm{kWh} \text { ) }\end{array}$} \\
\hline & Absolute & (Diff.) & Absolute & (Diff.) \\
\hline Reference & 273 & & 109 & \\
\hline Arvesen [23]—Lit. & 308 & $(12.8 \%)$ & 110 & $(0.9 \%)$ \\
\hline Birkeland [34]_Lit. & 215 & $(-21.2 \%)$ & 108 & $(-0.9 \%)$ \\
\hline May [48]-Calc. & 248 & $(-9.1 \%)$ & 109 & $(0.0 \%)$ \\
\hline ABB [49]—Calc. & 252 & $(-7.7 \%)$ & 109 & $(0.0 \%)$ \\
\hline Birkeland [34]—Calc. & 344 & $(26.0 \%)$ & 111 & $(1.8 \%)$ \\
\hline [34]—Calc. (reference) & 344 & & 111 & \\
\hline [34]_Calc.-Steel (R) & 304 & $(-11.6 \%)$ & 110 & $(-0.8 \%)$ \\
\hline [34]_Calc.-Steel (P) & 375 & $(9.1 \%)$ & 112 & $(0.6 \%)$ \\
\hline [34]-Calc.-Copper (R) & 315 & $(-8.4 \%)$ & 110 & $(-0.6 \%)$ \\
\hline [34]-Calc.-Copper (P) & 363 & $(5.5 \%)$ & 111 & $(0.4 \%)$ \\
\hline
\end{tabular}


Figure A1 presents a Sankey diagram of the energy flows and the losses along the way from Tennant Creek to Singapore for the reference scenario. The largest losses are attributed to the solar PV system while the lowest are taken by the battery storage system. Figures A2 and A3 show the hourly load and annual load duration curves of power demand in Singapore, PV output at Australia after losses and electricity import from Australia to Singapore, respectively. Figures A4 and A5 show the contributions of different components toward the emissions of the battery and cable, respectively.

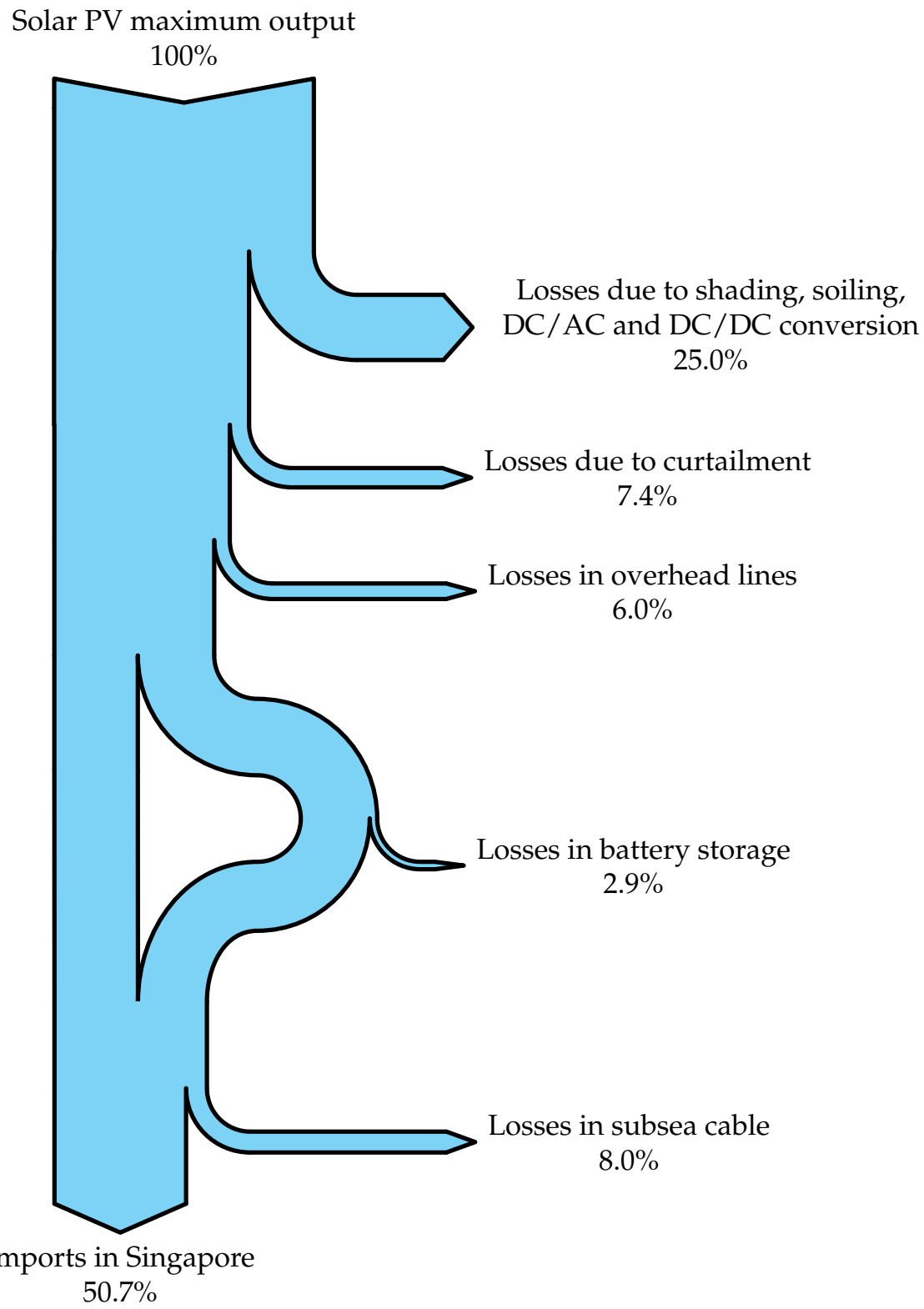

Figure A1. Sankey diagram showing the energy flows and the losses along the way from Tennant Creek to Singapore in the reference scenario. 


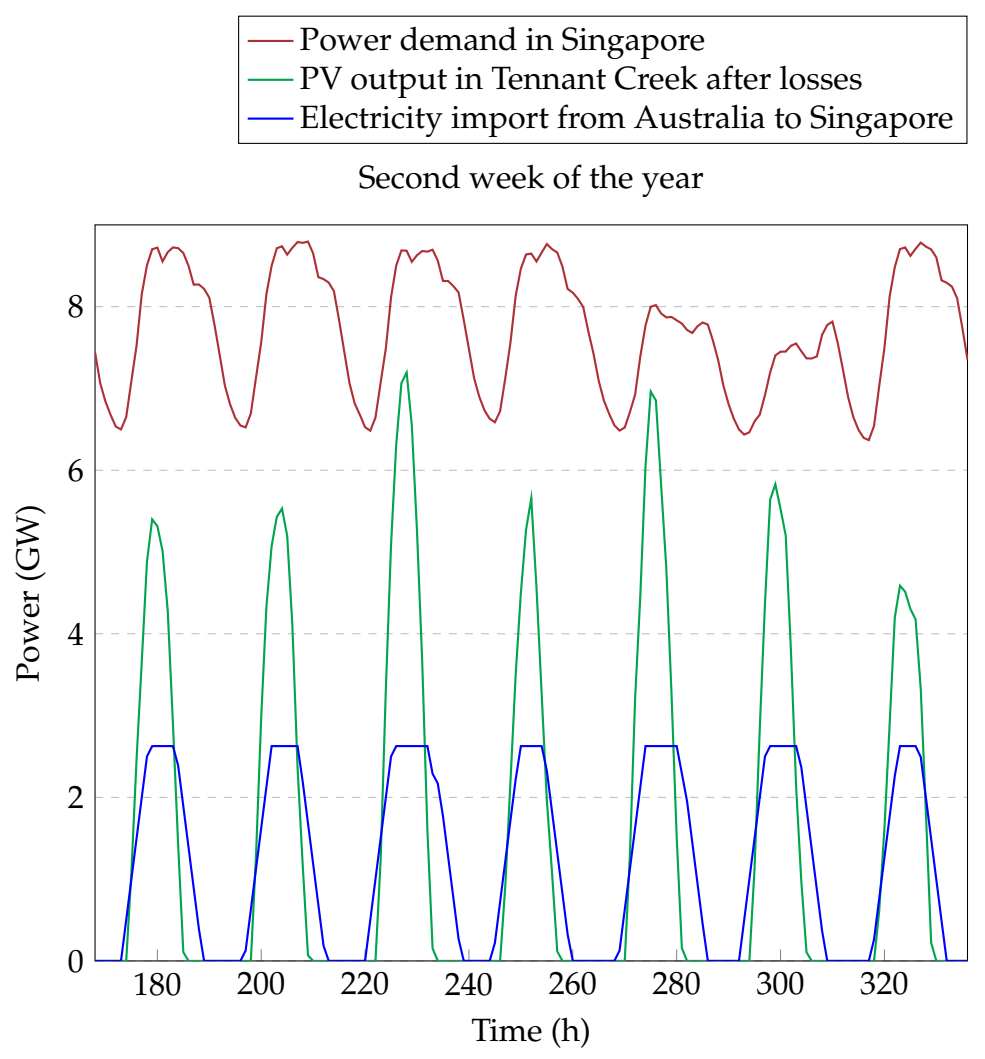

Figure A2. Hourly power demand in Singapore (maroon), PV system output in Tennant Creek (green), and import through the HVDC cable (blue) for a week in January. The difference between the green and blue curve is due to losses in transmission and storage. The use of a large battery system leads to peak shaving and shifting of the power supply to later hours.

Annual load duration curves

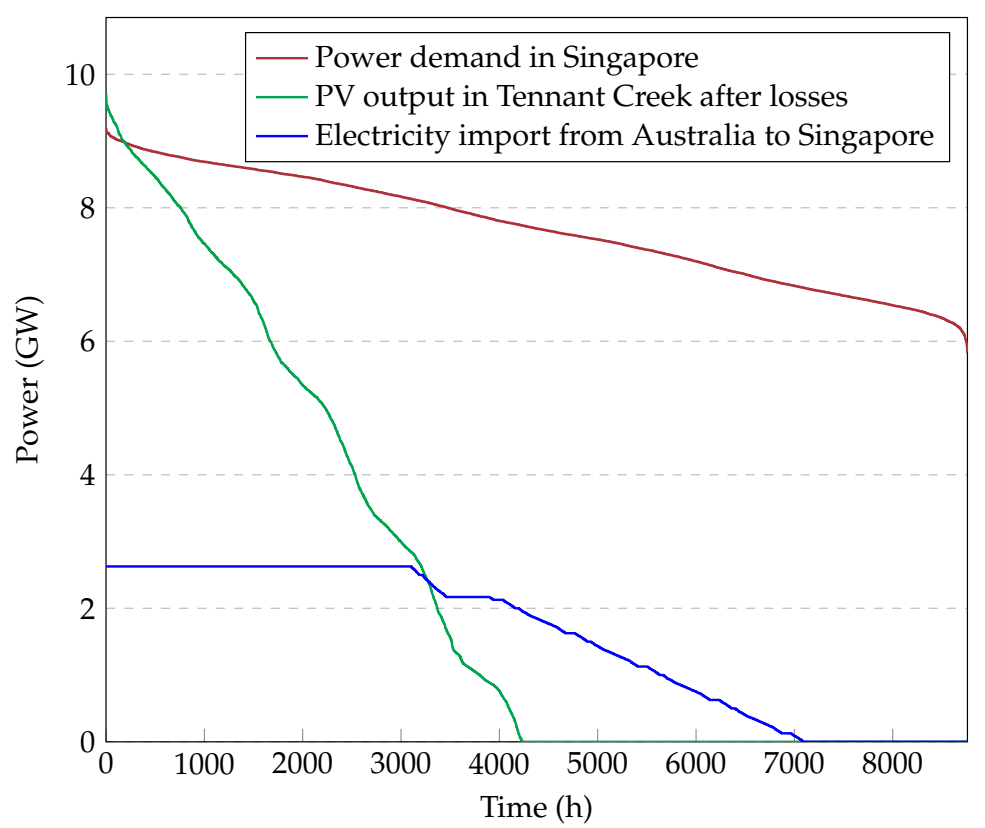

Figure A3. Sorted annual load duration curve of Singapore (maroon), PV system output in Tennant Creek (green), and imports through the HVDC cable (blue). The effect of the battery system is clearly visible in the extension of the time window of solar supply. The ramping constraint at the point of entry in the Singaporean grid affects the slope of the blue curve (roughly between hours 4000 and 7000). If the constraint is stricter, the blue curve is flattened even further, which means that the batteries have to be larger and the HVDC cable can be marginally smaller. 


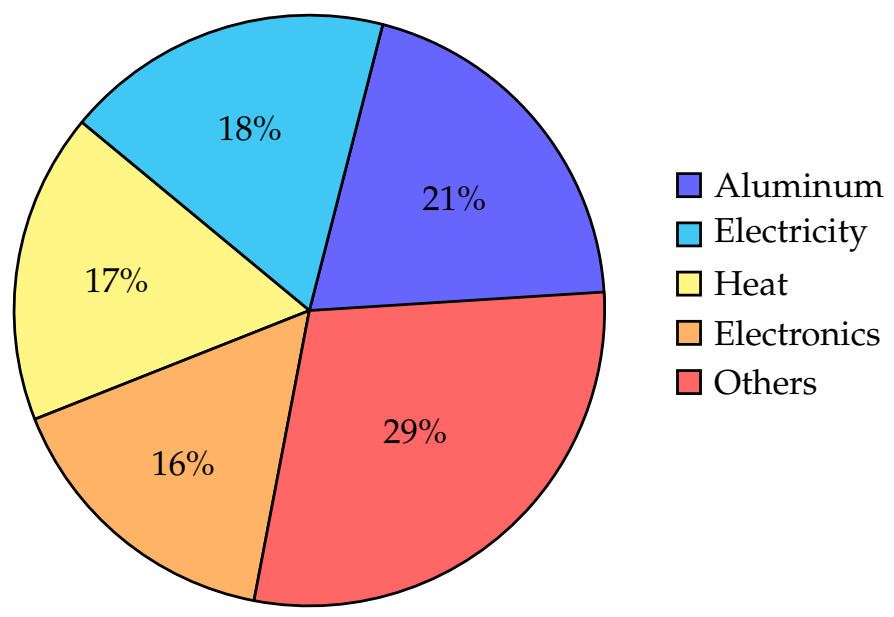

Figure A4. The contributions of the various components toward the emissions of the battery system.

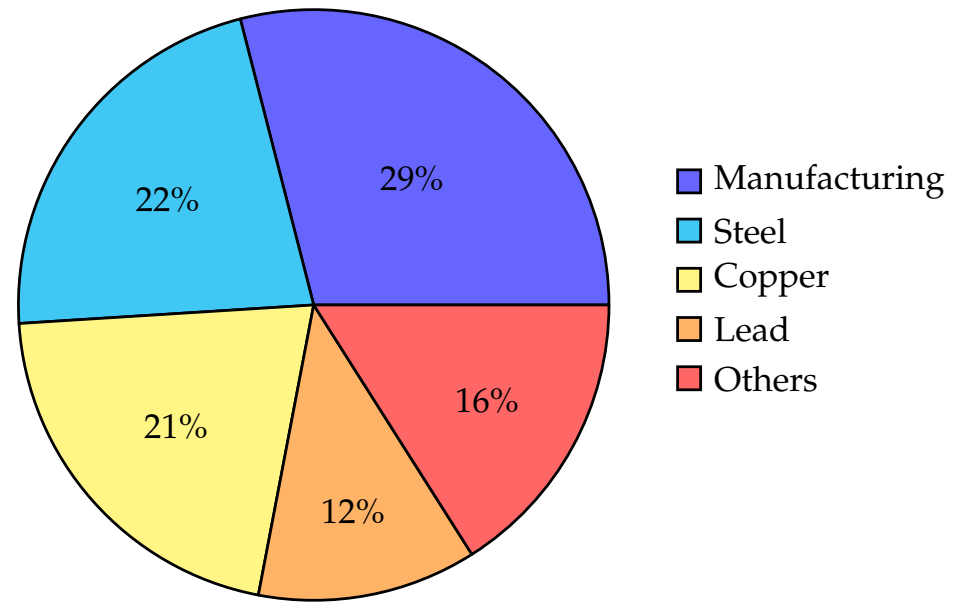

Figure A5. The contributions of the various components toward the emissions of the cable.

\section{References}

1. National Climate Change Secretariat. Singapore's Climate Action Plan: Take Action Today, for a Carbon-Efficient Singapore. Technical Report. NCCS. 2016. Available online: https://www.nccs.gov.sg/docs/default-source/publications/take-actiontoday-for-a-carbon-efficient-singapore.pdf (accessed on 23 February 2021).

2. Karthikeya, B.R.; Negi, P.S.; Srikanth, N. Wind resource assessment for urban renewable energy application in Singapore. Renew. Energy 2016, 87, 403-414. [CrossRef]

3. National Climate Change Secretariat. Singapore's Approach to Alternative Energy. 2020. Available online: https://www.nccs. gov.sg/singapores-climate-action/singapore-approach-to-alternative-energy / (accessed on 3 February 2021).

4. Solar Energy Research Institute of Singapore (SERIS). Update of the Solar Photovoltaic (PV) Roadmap for Singapore; Technical Report; SERIS, National University of Singapore: Singapore, 2020. Available online: http://www.seris.sg/doc/publications/Update-ofthe-Solar-Roadmap-for-Singapore-(March-2020).pdf (accessed on 16 June 2020).

5. Stich, J.; Mannhart, M.; Zipperle, T.; Massier, T.; Huber, M. Modelling a Low-carbon Power System for Indonesia, Malaysia and Singapore. In Proceedings of the 33rd International Energy Workshop; ERI-NDRC: Beijing, China, 2014; pp. 1-11. [CrossRef]

6. Quek, T.Y.A.; Alvin Ee, W.L.; Chen, W.; Ng, T.A. Environmental Impacts of Transitioning to Renewable Electricity for Singapore and the Surrounding Region: A Life Cycle Assessment. J. Clean. Prod. 2019, 214, 1-11. [CrossRef]

7. Siala, K.; Stich, J. Estimation of the PV Potential in ASEAN with a High Spatial and Temporal Resolution. Renew. Energy 2016, 88, 445-456. [CrossRef]

8. Stich, J.; Ramachandran, S.; Hamacher, T.; Stimming, U. Techno-economic Estimation of the Power Generation Potential from Biomass Residues in Southeast Asia. Energy 2017, 135, 930-942. [CrossRef]

9. Stich, J.; Massier, T. Enhancing the Integration of Renewables by Trans-border Electricity Trade in ASEAN. In Proceedings of the 2015 IEEE PES Asia-Pacific Power and Energy Engineering Conference (APPEEC), Brisbane, Australia, 15-18 November 2015; pp. 1-5. [CrossRef] 
10. Ahmed, T.; Mekhilef, S.; Shah, R.; Mithulananthan, N.; Seyedmahmoudian, M.; Horan, B. ASEAN Power Grid: A Secure Transmission Infrastructure for Clean and Sustainable Energy for South-East Asia. Renew. Sustain. Energy Rev. 2017, 67, 1420-1435. [CrossRef]

11. Ahmed, T.; Mekhilef, S.; Shah, R.; Mithulananthan, N. Investigation into Transmission Options for Cross-border Power Trading in ASEAN Power Grid. Energy Policy 2017, 108, 91-101. [CrossRef]

12. Huang, Y.W.; Kittner, N.; Kammen, D.M. ASEAN Grid Flexibility: Preparedness for Grid Integration of Renewable Energy. Energy Policy 2019, 128, 711-726. [CrossRef]

13. Jiang, H.; Gao, Y.; Xu, P.; Li, J. Study of Future Power Interconnection Scheme in ASEAN. Glob. Energy Interconnect. 2019, 2, 549-559. [CrossRef]

14. Sun Cable. Sun Cable-The World's Largest Solar Energy Infrastructure Project. 2019. Available online: https://www.suncable. sg/ (accessed on 7 August 2020).

15. Halawa, E.; James, G.; Shi, X.R.; Sari, N.H.; Nepal, R. The Prospect for an Australian-Asian Power Grid: A Critical Appraisal. Energies 2018, 11, 200. [CrossRef]

16. Blakers, A.; Luther, J.; Nadolny, A. Asia Pacific Super Grid-Solar Electricity Generation, Storage and Distribution. Green-Int. J. Sustain. Energy Convers. Storage 2012, 2, 189-202. [CrossRef]

17. Lu, B.; Blakers, A.; Stocks, M.; Do, T.N. Low-cost, Low-emission 100\% Renewable Electricity in Southeast Asia Supported by Pumped Hydro Storage. Energy 2021, 236, 121387. [CrossRef]

18. Wang, C.; Dargaville, R.; Jeppesen, M. Power system decarbonisation with Global Energy Interconnection-A case study on the economic viability of international transmission network in Australasia. Glob. Energy Interconnect. 2018, 1, 507-519. [CrossRef]

19. Itiki, R.; Manjrekar, M.; Di Santo, S.G.; Machado, L.F.M. Technical feasibility of Japan-Taiwan-Philippines HVdc interconnector to the Asia Pacific Super Grid. Renew. Sustain. Energy Rev. 2020, 133, 110161. [CrossRef]

20. Gulagi, A.; Bogdanov, D.; Breyer, C. A Cost Optimized Fully Sustainable Power System for Southeast Asia and the Pacific Rim. Energies 2017, 10, 583. [CrossRef]

21. Boie, I.; Kost, C.; Bohn, S.; Agsten, M.; Bretschneider, P.; Snigovyi, O.; Pudlik, M.; Ragwitz, M.; Schlegl, T.; Westermann, D. Opportunities and challenges of high renewable energy deployment and electricity exchange for North Africa and EuropeScenarios for power sector and transmission infrastructure in 2030 and 2050. Renew. Energy 2016, 87, 130-144. [CrossRef]

22. Jorge, R.S.; Hawkins, T.R.; Hertwich, E.G. Life cycle assessment of electricity transmission and distribution - Part 1: Power lines and cables. Int. J. Life Cycle Assess. 2012, 17, 9-15. [CrossRef]

23. Arvesen, A.; Nes, R.N.; Huertas-Hernando, D.; Hertwich, E.G. Life Cycle Assessment of an Offshore Grid Interconnecting Wind Farms and Customers Across the North Sea. Int. J. Life Cycle Assess. 2014, 19, 826-837. [CrossRef]

24. Harrison, G.P.; Maclean, E.N.J.; Karamanlis, S.; Ochoa, L.F. Life Cycle Assessment of the Transmission Network in Great Britain. Energy Policy 2010, 38, 3622-3631. [CrossRef]

25. Jorge, R.S.; Hertwich, E.G. Environmental Evaluation of Power transmission in Norway. Appl. Energy 2013, 101, 513-520. [CrossRef]

26. Kiss, B.; Kácsor, E.; Szalaya, Z. Environmental assessment of future electricity mix—Linking an hourly economic model with LCA. J. Clean. Prod. 2020, 264, 121536. [CrossRef]

27. Orfanos, N.; Mitzelos, D.; Sagani, A.; Dedoussis, V. Life-cycle environmental performance assessment of electricity generation and transmission systems in Greece. Renew. Energy 2019, 139, 1447-1462. [CrossRef]

28. Dorfner, J.; Schönleber, K.; Dorfner, M.; Candas, S.; Leonhard, B.; Odersky, L.; Ozsahin, Y.; Zipperle, T.; Herzog, S.; Siala, K.; et al. urbs v1.0.1: A Linear Optimisation Model for Distributed Energy Systems. Software Repository. 2019. Available online: https://urbs.readthedocs.io/en/latest/ (accessed on 19 October 2021). [CrossRef]

29. Siala, K. urbs Model for the SunCable Project. Software Repository. 2021. Available online: https://zenodo.org/record/4486189\# .YXuQM55BxPY (accessed on 1 February 2021). [CrossRef]

30. Energy Market Authority of Singapore. 2020. Available online: https://www.ema.gov.sg/statistic.aspx?sta_sid=20140802 apItNJRIa9Pa (accessed on 10 December 2020).

31. International Organization for Standardization Central Secretary. Environmental Management_Life Cycle Assessment_-Principles and Framework; Standard ISO 14040:2006; International Organization for Standardization: Geneva, Switzerland, 2006. Available online: https: / / www.iso.org/standard/37456.html (accessed on 10 December 2020).

32. International Organization for Standardization Central Secretary. Environmental Management_Life Cycle Assessment—Requirements and Guidelines; Standard ISO 14044:2006; International Organization for Standardization: Geneva, Switzerland, 2006. Available online: https: / /www.iso.org/standard/38498.html (accessed on 10 December 2020).

33. Ecoinvent. The Ecoinvent Database. 2020. Available online: https://www.ecoinvent.org/database/database.html (accessed on 2 December 2020).

34. Birkeland, C. Assessing the Life Cycle Environmental Impacts of Offshore Wind Power Generation and Power Transmission in the North Sea. Master's Thesis, Norwegian University of Science and Technology (Norges Teknisk-Naturvitenskaplige Universitet), Trondheim, Norway, 2011. 
35. Stocker, T.F.; Qin, D.; Plattner, G.K.; Tignor, M.; Allen, S.K.; Boschung, J.; Nauels, A.; Xia, Y.; Bex, V.; Midgley, P.M. Climate Change 2013: The Physical Science Basis. Contribution of Working Group I to the Fifth Assessment Report of the Intergovernmental Panel on Climate Change; Technical Report; IPCC: Cambridge, UK; New York, NY, USA, 2013. Available online: https://www.ipcc.ch/ report/ar5/wg1/ (accessed on 24 February 2021).

36. Energy Market Authority of Singapore. Electricity Generation Capacity by Generator (Sheet 29RSU). 2020. Available online: https:/ / www.ema.gov.sg/statistic.aspx?sta_sid=20141211PlH5tAbg9BY8 (accessed on 10 December 2020).

37. Energy Market Authority. Half-Hourly System Demand Data. 2020. Available online: https://www.ema.gov.sg/statistic.aspx? sta_sid=20140826Y84sgBebjwKV (accessed on 10 December 2020).

38. Lacal Arantegui, R.; Jaeger-Waldau, A.; Vellei, M.; Sigfusson, B.; Magagna, D.; Jakubcionis, M.; Perez Fortes, M.d.M.; Lazarou, S.; Giuntoli, J.; Weidner Ronnefeld, E.; et al. ETRI 2014—Energy Technology Reference Indicator Projections for 2010-2050; EURScientific and Technical Research Reports; Joint Research Center of the European Union: Petten, The Netherlands, 2014. [CrossRef]

39. Lauria, D.; Mazzanti, G.; Quaia, S. Per-unit power costs of traditional and innovative OHLs: A multi-criteria comparison. IET Gener. Transm. Distrib. 2016, 10, 3033-3040. [CrossRef]

40. International Energy Agency. World Energy Outlook 2019; OECD Publishing: Paris, France, 2019. [CrossRef]

41. Siala, K.; Houmy, H. tum-ens/pyGRETA: Python Generator of REnewable Time Series and mAps. Software Repository. 2020. Available online: https:/ / zenodo.org/record/3872068\#.YXuTBZ5BxPY (accessed on 1 February 2021). [CrossRef]

42. REC Group. Factsheet REC Alpha Series; Technical Factsheet; REC Solar Holdings AS: Singapore, 2020. Available online: https://www.recgroup.com/sites/default/files/documents/ds_rec_alpha_series_en_us.pdf (accessed on 5 April 2021).

43. Dai, Q.; Kelly, J.C.; Gaines, L.; Wang, M. Life Cycle Analysis of Lithium-Ion Batteries for Automotive Applications. Batteries 2019, 5, 48. [CrossRef]

44. International Energy Agency. Data and Statistics. 2021. Available online: https://www.iea.org/data-and-statistics?country= WORLD\&fuel=Energy\%20supply\&indicator=TPESbySource (accessed on 5 April 2021).

45. NREL. Life Cycle Greenhouse Gas Emissions From Solar Photovoltaics; Technical Report; National Renewable Energy Laboratory: Golden, CO, USA, 2012. Available online: https:/ / www.nrel.gov/docs/fy13osti/56487.pdf (accessed on 15 March 2012).

46. Ardelean, M.; Minnebo, P. HVDC Submarine Power Cables in the World; Technical Report EUR 27527 EN; Joint Research Centre, The European Commission: Den Haag, The Netherlands, 2015. [CrossRef]

47. Mazzanti, G.; Marzinotto, M. Extruded Cables for High-Voltage Direct-Current Transmission: Advances in Research and Development; Wiley-IEEE Press: Hoboken, NJ, USA, 2013; Volume 93. [CrossRef]

48. May, N. Ecobalance of a Solar Electricity Transmission from North Africa to Europe. Diploma Thesis, Technical University of Braunschweig, Braunschweig, Germany, 2005.

49. ABB. Submarine Cable Design Sheet-1000 MW. 2014. Available online: http://www.necplink.com/docs/Champlain_ VT_electronic/04\%20L.\%20Eng/Exh.\%20TDI-LE-4\%20(HVDC\%20Cable\%20Design\%20Sheet\%20(ABB)).pdf (accessed on 20 February 2021).

50. Gelaro, R.; McCarty, W.; Suárez, M.J.; Todling, R.; Molod, A.; Takacs, L.; Randles, C.A.; Darmenov, A.; Bosilovich, M.G.; Reichle, R.; et al. The Modern-Era Retrospective Analysis for Research and Applications, Version 2 (MERRA-2). J. Clim. 2017, 30, 5419-5454. [CrossRef]

51. de Atholia, T.; Flannigan, G.; Lai, S. Renewable Energy Investment in Australia; Technical Report; Reserve Bank of Australia: Sydney, Australia, 2020. Available online: https://www.rba.gov.au/publications/bulletin/2020/mar/pdf/renewable-energyinvestment-in-australia.pdf (accessed on 2 October 2021).

52. European Union. Directive 2009/28/EC of the European Parliament and of the Council of 23 April 2009 on the promotion of the use of energy from renewable sources and amending and subsequently repealing Directives 2001/77/EC and 2003/30/EC. Off. J. Eur. Union 2009, 52, 16-62. [CrossRef]

53. Silalahi, D.F.; Blakers, A.; Stocks, M.; Lu, B.; Cheng, C.; Hayes, L. Indonesia's Vast Solar Energy Potential. Energies 2021, 14, 5424. [CrossRef]

54. Bolton, C. World's Largest Floating Solar Farm-More Than 2GW-To Supply Singapore. 2021. Available online: https: //www.narecsolar.com/worlds-largest-floating-solar-farm-more-than-2gw-to-supply-singapore/ (accessed on 5 October 2021).

55. Lammerant, J.; Laureysens, I.; Driesen, K. Potential Impacts of Solar, Geothermal and Ocean Energy on Habitats and Species Protected under the Birds and Habitats Directives. Final Report under EC Contract ENV.D.3/SER/2017/0002; Technical Report; Arcadis Belgium, Institute for European Environmental Policy, BirdLife International, NIRAS, Stella Consulting, Ecosystems Ltd.: Brussels, Belgium, 2020. Available online: https:/ / ec.europa.eu/environment/nature/natura2000/management/docs/POTENTIAL\% 20IMPACTS\%20OF\%20SOLAR_\%20GEOTHERMAL\%20AND\%20OCEAN\%20ENERGY\%20ON\%20HABITATS\%20AND\%20 SPECIES\%20PROTECTED\%20UNDER\%20THE\%20BIRDS\%20AND\%20HABITATS\%20DIRECTIVES\%20-\%20Final\%20report. pdf (accessed on 5 October 2021). 